\title{
Why Title VII Should Prohibit All \\ Workplace Sexual Harassment
}

\author{
Brian Lehman $^{\dagger}$
}

I. AN ANALYTICAL FRAMEWORK FOR UNDERSTANDING TITLE VII

A. When the Typical Case of Sexual Harassment

Violates Title VII.

B. The Principal Criticism: Not all sexual harassment is

sex discrimination

1. The Sexual Harassment of Heterosexual Men.

2. The Sexual Harassment of Lesbians and Gay Men.

II. Prohibiting Sexual Harassment as a Rule of AdJudication

A. Examining the "Error" Costs and "Decision" Costs .......................... 238

1. Error Costs.

2. Decision Costs

B. Other Values Promoted by a Per Se Rule 244

C. Equal Protection: Tying it together

III.WHEN CONDUCT Proves CAUSATION: NeW Doctrine, OLD DOCTRINE, SAME DOCTRINE

A. New Doctrine: Sexual harassment after Oncale

B. Old Doctrine: When impact proves causation under Title VII.

C. Same Doctrine: When conduct proves causation outside discrimination law.

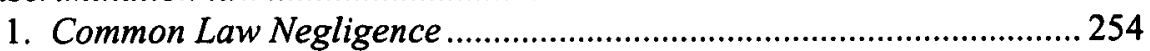

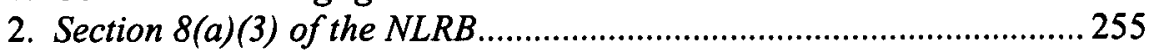

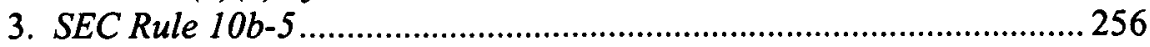

4. Ineffective Counsel and Strickland v. Washington ......................... 256

IV. CONCLUSION

† J.D., The University of Chicago Law School. I am grateful to Victoria Brescoll, Catharine MacKinnon and Cass Sunstein for their comments and discussions. I would also like to thank Elidia Chapa, Jessica Clarke, Lucy Fowler, Ben Gutman, Lenore Horowitz, Marci Reichbach, Jennifer Stuart and the editorial staff of the Yale Journal of Law and Feminism for their suggestions. Portions of this article are from Brian Lehman, The Equal Protection Problem in Sexual Harassment Doctrine, 10 COLUM. J. GENDER \& L. 125 (2000). The author may be contacted at brian.lehman@aya.yale.edu. 


\section{INTRODUCTION}

Over the last decade, courts have increasingly struggled with a problem in sexual harassment doctrine: Title VII, the statute under which most federal claims of sexual harassment are brought, does not explicitly prohibit sexual harassment. Instead, the statute makes it unlawful for an employer to discriminate "against any individual with respect to his compensation, terms, conditions, or privileges of employment, because of such individual's ... sex."'

Legal scholars have given two explanations for why sexual harassment is unlawful under Title VII. In one camp, scholars have argued that sexual harassment is unlawful because it is "a form of sex discrimination." These scholars have focused on defining discrimination and explaining why sexual harassment qualifies as discrimination under their definition. ${ }^{2}$ The argument then becomes a syllogism: Title VII prohibits sex discrimination; sexual harassment is sex discrimination; therefore, Title VII prohibits sexual harassment. For example, Catharine MacKinnon argued over twenty years ago that all sexual harassment is sex discrimination because the act reinforces the social inequality of women to men. ${ }^{3}$

In the other camp, scholars have argued that Title VII does not necessarily prohibit all sexual harassment because the statute only makes it illegal for employers to treat men and women differently. ${ }^{4}$ Under this definition of sex

1. 42 U.S.C. $\$ 2000 \mathrm{e}-2$ (a) (2000). See infra note 14 for the statute's text.

2. E.g., Catharine a. Mackinnon, Sexual harassment of Working Women: a Case of Sex DISCRIMINATION 116-18 (1979) (arguing that sexual harassment is sex discrimination because it reinforces the social inequality of women to men); Kathryn Abrams, The New Jurisprudence of Sexual Harassment, 83 CORNELL L. REV. 1169, 1172 (1998) (arguing for a new theory of sexual harassment that characterizes sexual harassment as "a phenomenon to preserve male control and entrench masculine norms"); Katherine M. Franke, What's Wrong with Sexual Harassment, 49 STAN. L. REV. 691, 772 (1997) (arguing that sexual harassment "is a practice, grounded and undertaken in the service of hetero-patriarchal norms. These norms, regulatory, constitutive, and punitive in nature, produce gendered subjects: feminine women as sex objects and masculine men as sex subjects. On this account, sexual harassment is sex discrimination precisely because its use and effect police hetero-patriarchal gender norms in the workplace . . ." (emphasis added)); Vicki Schultz, Reconceptualizing Sexual Harassment, 107 YALE L.J. 1683, 1775, 1803 (1998) (arguing that "harassment has the form and function of denigrating women's competence for the purpose of keeping them away from maledominated jobs or incorporating them as inferior, less capable workers" and that courts should adopt a "'competence centered" paradigm, for it understands harassment as a means to reclaim favored lines of work and work competence as masculine-identified turf . . . . [As case law shows] hostile work environment harassment is simply a form of gender discrimination" (emphasis added)); Linda B. Epstein, Note, What Is a Gender Norm and Why Should We Care? Implementing a New Theory in Sexual Harassment Law, 51 STAN. L. REV. 161, 180-81 (1998) (arguing that courts should apply a "unified theory of gender-norm harassment that encompasses sexual and nonsexual but sex-based conduct .... [ $[\mathrm{f}$ sexualizing women was recast as enforcing upon women the gender norm of 'sexual object,' that enforcement is inherently a discriminatory one" (emphasis added)).

3. MACKINNON, supra note 2, at 174.

4. E.g., Rebecca Hanner White, There's Nothing Special About Sex: The Supreme Court Mainstreams Sexual Harassment, 7 WM. \& MARY BILL RTS. J. 725, 735 (1999) (arguing that the Supreme Court merged sexual harassment with other types of Title VII claims and that employers are not necessarily liable for all sexual harassment); Steven L. Willborn, Taking Discrimination Seriously: Oncale and the Fare of Exceptionalism in Sexual Harassment Law, 7 WM. \& MARY BILL RTS. J. 677, 723 (1999) (arguing courts should treat Title VII's discrimination element seriously and find that discrimination only exists whenever women are treated differently than men). 
discrimination, Title VII prohibits sexual harassment only if it happens because an employee is male or female. Every Title VII claim thus involves a question of causation: "But for" the plaintiffs' sex would they have been treated differently? For example, if an employer sexually harasses employees when they advocate feminist beliefs, the employer is treating them poorly not because of their sex but "because of" their political views, and such sexual harassment would not be unlawful.

Courts have fluctuated between these two incompatible approaches depending on the type of case being decided. In the paradigmatic case of a heterosexual man sexually harassing a heterosexual woman, courts have frequently stated that "sexual harassment is a form of sex discrimination." These courts have held that the plaintiff has a claim if she proves that she was sexually harassed. ${ }^{7}$ But in cases of same-sex sexual harassment or the sexual harassment of gay men and lesbians, courts have held that employers are not necessarily liable even if the plaintiff was sexually harassed. ${ }^{8}$ These courts have emphasized that Title VII's crucial inquiry is not whether the plaintiff was

5. E.g., Willbom, supra note 4, at 704 . This view is consistent with early sexual harassment cases that explicitly adopted a "but for" causation analysis. See infra note 16 and accompanying text.

6. E.g., Provencher v. CVS Pharmacy, 145 F.3d 5, 13 (1st Cir. 1998) ("Sexual harassment is a form of gender discrimination prohibited by Title VIl."); Sprague v. Thom Ams., Inc., 129 F.3d 1355, 1365 (10th Cir. 1997) ("It is beyond contention that Title VII prohibits sexual harassment in the workplace."); Fleming v. Boeing Co., 120 F.3d 242, 244 (11th Cir. 1997) ("Sexual harassment is a form of sexual discrimination within the meaning of Title VII."); Mattem v. Eastman Kodak Co., 104 F.3d 702, 715 (5th Cir. 1997) ("A claim of 'hostile environment' sexual harassment is a form of sex discrimination that is actionable under Title VII."); Bator v. Hawaii, 39 F.3d 1021, 1028-29 (9th Cir. 1994) ("Courts have recognized that sexual harassment is sex discrimination in violation of Title VII at least since 1977."); Poe v. Haydon, 853 F.2d 418, 428 (6th Cir. 1988) ("[T]he Supreme Court ruled [in Meritor] that "hostile environment' sexual harassment is a form of sex discrimination.").

7. That is, courts have prohibited sexual harassment per se in these cases, although the standard approach has taken two forms. See Willbom, supra note 4, at 681-83. The first form is exemplified by the Ninth Circuit which does not make "discrimination because of such individual's sex" an explicit element of the cause of action. Thus, to prevail at trial, plaintiffs must prove they were

1) subjected to sexual advances, requests for sexual favors, or other verbal or physical conduct of a sexual nature; 2) the conduct was unwelcome; and 3) that the harassment affected a tangible aspect of employment; or the conduct was sufficiently severe or pervasive to alter the conditions of employment and create an abusive working environment.

Ellison v. Brady, 924 F.2d 872, 875-76 (9th Cir. 1991); Jordan v. Clark, 847 F.2d 1368, 1373 (9th Cir. 1988). This is also consistent with the Equal Employment Opportunities Commission's definition. See infra note 23 (providing EEOC's definition).

The second form of the standard test requires, as a formal matter, that the plaintiff prove the harassment was "based on sex" or happened "because of sex" in addition to the other elements. In most cases involving sexual conduct, however, courts have simply assumed that that the conduct was sex discrimination, especially if the case involved male-female harassment. See Willborn, supra note 4, at 682-83. Indeed, I have not found a single case decided before Oncale in which a man sexually harassed a woman and the court held that the "because of such individual's sex" element was not satisfied.

8. E.g., McWilliams v. Fairfax County Bd. of Supervisors, 72 F.3d 1191, 1195-96 (4th Cir. 1996) (emphasizing the "because of sex" requirement in same-sex sexual harassment case and holding that McWilliams was not sexually harassed "because of" his sex but for other reasons, perhaps "because of" his "known or believed prudery, or shyness"); Higgins v. New Balance Athletic Shoe, Inc., 21 F. Supp. 2d 66, 73 (D. Me. 1998) (holding that frequent verbal and physical abuse involving sexual conduct by supervisors and co-workers because of animus toward plaintiff's sexual orientation is not "because of sex" and plaintiff must offer sex-based evidence to show harassment under Oncale); Martin v. Norfolk S. Ry. Co., 926 F. Supp. 1044, 1049-50 (N.D. Ala. 1996) (holding that same-sex hostile environment cases with heterosexual harassers did not provide any assurance that the conduct occurred because of the victim's sex). 
sexually harassed, but whether the plaintiff would have been treated differently if the plaintiff had been the opposite sex. ${ }^{9}$

The goal of this article is to show why courts may legitimately prohibit all sexual harassment regardless of the approach they adopt or their definition of discrimination. Thus, the basic conclusion is that plaintiffs should have a Title VII claim if they prove that they were sexually harassed, regardless of their sex, sexual orientation or any other fact. ${ }^{10}$ The article's central point is that one must make two claims to conclude that interpreting Title VII to prohibit all workplace sexual harassment is illegitimate. The first claim is that "discrimination because of such individual's sex" means treating men and women differently. Academic literature and courts have focused exclusively on this point when arguing against prohibiting all sexual harassment. However, critics must make a second claim for their conclusion to follow. Specifically, they must argue that courts may not interpret Title VII in such an overinclusive manner as to prohibit all sexual harassment. Thus far, this argument has not received any attention.

This article assumes, arguendo, that sex discrimination means treating men and women differently but nonetheless concludes that courts should prohibit all sexual harassment because it serves as a good adjudicative rule to apply to individual cases. Rules always produce mistakes by sweeping too broadly or narrowly if measured against the reasons that justify them. Nonetheless, courts legitimately (and frequently) use judicially made rules to decide cases because they serve other values that the law seeks to promote. Specifically, rules lower the costs of making individual decisions, reduce arbitrary and biased decisions, and increase predictability for those affected by the law. These virtues justify prohibiting all sexual harassment under Title VII. If this argument is correct, even those who argue that the proper interpretation of Title VII means employers may not "treat men and women differently" should nonetheless agree that courts can legitimately prohibit all sexual harassment. ${ }^{11}$

This article is organized as follows. Part I of the article explores the argument that sex discrimination means treating men and women differently and proposes a framework for understanding when sexual harassment meets this definition. Part II examines why courts should prohibit all sexual harassment regardless of the victim's sex, sexual orientation or any other personal

9. E.g., Oncale v. Sundowner Offshore Servs., 523 U.S. 75, 81 (1998) (stating in same-sex sexual harassment case that "[w]hatever evidentiary route the plaintiff chooses to follow, he or she must always prove that the conduct at issue was not merely tinged with offensive sexual connotations, but actually constituted 'discrimina[tion] . . . because of . . . sex." "); McWilliams, 72 F.3d at 1195 (emphasizing Title VII's "because of sex" requirement).

10. Of course, a plaintiff must still prove that the employer is in some way responsible, and hence liable, for the sexual harassment.

11. In this way, I am arguing for an "incompletely theorized agreement"-an agreement that sexual harassment is illegal under Title VII to which people with competing views of the appropriate interpretation of Title VII can subscribe. See Cass R. Sunstein, Incompletely Theorized Agreements, 108 HARV. L. REv. 1733, 1739-42 (1995) (describing "incompletely theorized agreements" as agreements on a particular issue without agreement on the underlying principle and suggesting that such a strategy can promote consensus in a pluralistic democracy); see also CASS R. SUNSTEIN, LEGAL REASONING AND POLITICAL CONFLICT 35-44 (1996) (arguing that well-functioning legal systems tend to produce incompletely theorized agreements). 
characteristic. This part applies the previous framework to examine how a categorical prohibition of sexual harassment would sweep too broadly. It then examines the virtues of adopting a bright-line rule against sexual harassment. Part III places the argument in a broader judicial context. It first suggests the direction courts should take after the Supreme Court's decision in Oncale v. Sundowner Offshore Services. ${ }^{12}$ It then situates sexual harassment within current Title VII doctrine as a whole. Finally, it examines areas of law outside Title VII in which courts must answer a question of causation or whether something happened "because of" something else. In each area, one can find examples of courts answering these questions by drawing bright-line rules based on the proof of a particular fact or conduct. Thus, prohibiting all sexual harassment under a statute that prohibits sex discrimination can be viewed as part of a common approach taken by courts when deciding questions of causation.

\section{AN ANALYTICAL FRAMEWORK FOR UNDERSTANDING TITLE VII}

According to those who assert that Title VII does not prohibit all sexual harassment, the statute focuses on two things: the employer's behavior and the reasons motivating that behavior. ${ }^{13}$ First, the employer's behavior must affect the "compensation, terms, conditions, or privileges of employment." Second, such behavior must happen "because of such individual's . . . sex." consider that no federal law prohibits an employer from hiring, promoting or terminating employees because they are politically liberal. Title VII does prohibit the same behavior, however, if it happens because the employee is a woman or a man. Thus, a key to understanding this approach to Title VII is to separate an employer's behavior from an employer's motives.

The text of Title VII, of course, does not prohibit sexual harassment. Rather, it prohibits sexual harassment that affects the "compensation, terms, conditions, or privileges of employment" and happens "because of such individual's . . sex." ${ }^{15}$ This approach seeks to answer a question of but-for causation: Would the employee have suffered the sexual harassment "but for" his or her sex? ${ }^{16}$

12. 523 U.S. 75 (1998).

13. I discussed this framework in Brian Lehman, The Equal Protection Problem in Sexual Harassment Doctrine, 10 COLUM. J. GENDER \& L. 125 (2000). Portions of this section are from that article.

14. Title VII reads in part:

It shall be an unlawful employment practice for an employer-

(1) to fail or refuse to hire or to discharge any individual, or otherwise to discriminate against any individual with respect to his compensation, terms, conditions, or privileges of employment, because of such individual's race, color, religion, sex, or national origin; or

(2) to limit, segregate, or classify his employees or applicants for employment in any way which would deprive or tend to deprive any individual of employment opportunities or otherwise adversely affect his status as an employee, because of such individual's race, color, religion, sex, or national origin.

42 U.S.C. $\S 2000 \mathrm{e}-2$ (a) (2000).

15. Id.

16. This interpretation has strong roots in the first cases to establish that sexual harassment violated Title VII. Bundy v. Jackson, 641 F.2d 934, 942 n.7 (D.C. Cir. 1981) ("[I]n each instance the question is one of butfor causation: would the complaining employee have suffered the harassment had he or she been of a different 
Because sexual harassment does not necessarily happen "because of such individual's sex," one must determine when it (or any other behavior) is motivated by the fact that the plaintiff is a woman or man-in the sense that it would not have happened to a similar person of the opposite sex.

In both case law and academic scholarship, one can identify three motives that meet the "but for" definition and distinguish acts that happen "because of such individual's sex" from acts that happen for other reasons. ${ }^{17}$ An employer's behavior qualifies as sex discrimination if motivated in part by (1) sexual attraction, (2) gender animus or (3) gender stereotypes. An employer motivated by these reasons, at least in part, treats the employee differently because of that person's sex; in each case, "but for" the employee's sex, the employer would not have treated him or her in such a fashion. It is important to note, however, that Title VII does not prohibit all behavior that falls into one of these categories because the conduct must still rise to the level of affecting the "compensation, terms, conditions, or privileges of employment." To expound on this framework, consider each motivation in turn.

Sexual attraction. If a person is sexually attracted to one sex, and acts on that desire, then the conduct is discriminatory. ${ }^{18}$ For example, if a heterosexual female employer assigns a male employee to a job because she is sexually attracted to him, her motive is discriminatory. "But for" his sex, he would not have been assigned to the job.

Gender animus. If a person hates one sex, and acts on that hate, then the conduct is discriminatory. An employer violates Title VII when he does not hire a qualified woman for a job because he hates women. "But for" the woman's sex, she would have been hired.

Gender stereotyping. If a person acts on gender stereotypes, then the conduct is discriminatory. Gender stereotypes consist of a set of beliefs about the

gender?") (first appellate case to establish a hostile environment claim of sexual harassment); Bames v. Costle, 561 F.2d 983, 990 (D.C. Cir. 1977) ("But for her womanhood, from aught that appears, her participation in sexual activity would never have been solicited.") (first appellate case to establish a quid pro quo claim of sexual harassment); see also Jones v. Flagship Int'l, 793 F.2d 714, 719 (5th Cir. 1986) ("[T] he harassment complained of was based upon sex, i.e., that but for the fact of her sex, the plaintiff would not have been the object of harassment"); McKinney v. Dole, 765 F.2d 1129, 1138 (D.C. Cir. 1985) ("[W]e hold that any harassment or other unequal treatment of an employee or group of employees that would not occur but for the sex of the employee or employees may, if sufficiently pattemed or pervasive, comprise an illegal condition of employment under Title VII."); Henson v. City of Dundee, 682 F.2d 897, 904 (11th Cir. 1982) ("In proving a claim for a hostile work environment due to sexual harassment, therefore, the plaintiff must show that but for the fact of her sex, she would not have been the object of harassment.").

17. Lehman, supra note 13 , at 137.

18. Thus, the "bisexual harasser" is not liable under Title VII because the behavior does not tum on the sex of the employee. See Henson, 682 F.2d at 905 n.11 (11th Cir. 1982) ("Except in the exceedingly atypical case of a bisexual supervisor, it should be clear that sexual harassment is discrimination based upon sex."); Bundy v. Jackson, 641 F.2d 934, 942 n.7 (D.C. Cir. 1981) ("Only by a reductio ad absurdum could we imagine a case of harassment that is not sex discrimination where a bisexual supervisor harasses men and women alike."); Barnes v. Costle, 561 F.2d 983, 990 n.55 (D.C. Cir. 1977) ("In the case of a bisexual superior, the insistence upon sexual favors would not constitute gender discrimination because it would apply to male and female employees alike."). See generally Sandra Levitsky, Footnote 55: Closing the "Bisexual Defense" Loophole in Title VII Sexual Harassment Cases, 80 MiNN. L. REV. 1013 (1996) (explaining the establishment of the bisexual defense loophole). 
characteristics men and women possess and the societal roles they occupy. ${ }^{19} \mathrm{~A}$ person can discriminate by relying on gender stereotypes in two ways. First, the stereotypes can serve as descriptive generalizations about men and women. For example, employers may assign women and men to different jobs because of the generalization that "men are more assertive and independent than women" or because women "make better secretaries."

Second, gender stereotypes can reflect beliefs about how men and women should act or behave. ${ }^{20}$ Thus, an employer may react adversely to women and men who do not conform to specific gender stereotypes. For instance, an employer may not promote a woman because she is "too aggressive" and lacks "interpersonal skills." 21 No particular animus towards women motivates the employer. Rather, the employer believes that men and women should act or behave in different ways. Nonetheless, "but for" her sex, the employee would not be thought too aggressive or lacking in interpersonal skills. ${ }^{22}$

\section{A. When the Typical Case of Sexual Harassment Violates Title VII}

This framework shows when the paradigmatic case of sexual harassment-a heterosexual male sexually harassing a heterosexual female-qualifies as sex discrimination. Over the last twenty years, courts have recognized two types of claims under the rubric of "sexual harassment": quid pro quo and hostile work environment claims. ${ }^{23}$ Quid pro quo harassment occurs when a supervisor seeks

19. Kay Deaux \& Marianne LaFrance, Gender, in 1 ThE HANDBOOK OF SOCIAL PSyChology 788, 793 (Daniel T. Gilbert et al. eds., 1998).

20. Id.

21. See Price Waterhouse v. Hopkins, 490 U.S. 228 (1989).

22. Behavior motivated by gender stereotypes is discriminatory only when it treats men and women differently, however. Thus, an employer does not violate Title VII if he hires (or fires) only independent and aggressive employees, even though such characteristics are typically viewed as "masculine." In comparison, employers do violate Title VII if they base employment decision on the expectations that women will not or should not act aggressively.

23. Catharine MacKinnon was the first person to divide sexual harassment claims into two categories. See MACKINNON, supra note 2, at 32-42. MacKinnon labeled the first type "quid pro quo," meaning sexual harassment "in which sexual compliance is exchanged, or proposed to be exchanged, for an employment opportunity." Id. at 32. According to MacKinnon, the second type "arises when sexual harassment is a persistent condition of work." Id. In 1980, the Equal Employment Opportunity Commission followed MacKinnon's framework in adopting guidelines prohibiting sexual harassment. The EEOC's guidelines on sexual harassment state in full:

Harassment on the basis of sex is a violation of section 703 of title VII. Unwelcome sexual advances, requests for sexual favors, and other verbal or physical conduct of a sexual nature constitute sexual harassment when (1) submission to such conduct is made either explicitly or implicitly a term or condition of an individual's employment, (2) submission to or rejection of such conduct by an individual is used as the basis for employment decisions affecting such individual, or (3) such conduct has the purpose or effect of unreasonably interfering with an individual's work performance or creating an intimidating, hostile, or offensive working environment.

29 C.F.R. § 1604.11(a) (2000). The first two subsections encompass "quid pro quo" harassment, while the third one refers to "hostile work environment" harassment. The Supreme Court recognized this distinction when it heard its first sexual harassment case. Meritor Sav. Bank v. Vinson, 477 U.S. 57, 64-65 (1986).

The Supreme Court weakened the distinction between quid pro quo and hostile work environment harassment in Burlington Industries v. Ellerth, 524 U.S. 742 (1998). Burlington rejected the distinction between quid pro quo and hostile environment harassment as a basis for determining whether to apply strict or 
sexual favors in return for job benefits. A common example of this harassment is the statement "sleep with me or you are fired." In comparison, hostile work environment harassment occurs when a harasser's sexual conduct creates an intimidating, hostile or offensive work environment. For example, a hostile work environment may be created if a supervisor repeatedly makes sexual innuendo about an employees' clothes, asks employees to retrieve coins from his pockets, calls co-workers "dumb ass [women]," and makes comments such as "We need a man as manager., 24

The discriminatory element behind quid pro quo claims is a sexual attraction aimed only at one sex. ${ }^{25}$ If a heterosexual male supervisor fires a female employee because she rejects his sexual advances, he has violated Title VII. The conduct is discriminatory because he would not have made sexual advances to a male employee.

In contrast, hostile work environment harassment may be motivated by sexual attraction, gender animus or gender stereotypes. Such a claim might involve a supervisor's repetitive and unwelcome sexual advances that create a hostile work environment. This would qualify as discriminatory for the same reasons quid pro quo claims violate Title VII (such behavior is not aimed at male employees).

Sexual desire, however, is not the only motive that qualifies certain behavior as sex discrimination. ${ }^{26} \mathrm{~A}$ man motivated by gender animus may sexually harass a woman because "[w]omen are only fit company for something that howls .... $[T]$ here's nothing worse than having to work around women."27 Or a man may sexually harass a woman because she is attempting to do a "man's job" or she needs to act "like a woman." Such a harasser may be trying to put the woman "in her place." In this case, gender stereotypes motivate the harasser. In each example, the sexual harassment qualifies as sex discrimination because it would not have happened "but for" the victim's sex.

\section{B. The Principal Criticism: Not all sexual harassment is sex discrimination}

Using this framework, one can discern the main objection to courts' holding all sexual harassment unlawful under Title VII: Sexual harassment does not necessarily happen because a person is a man or woman. A person might sexually harass an employee in a way that does not meet the "but for" test, in

negligence-based employer liability, respectively, for employees' behavior. Id. at 751-52. In rejecting that distinction, the Court stated, "The terms quid pro quo and hostile work environment are helpful, perhaps, in making a rough demarcation between cases in which threats are carried out and those where they are not or are absent altogether, but beyond this are of limited utility." Id. Thus, the principal difference between hostile work environment and quid pro quo is currently whether the harasser made a threat of adverse employment action and then carried it out (e.g., denied overtime or promotional opportunities).

24. Harris v. Forklift Sys., Inc., 510 U.S. 17, 18 (1993).

25. See supra note 18 (discussing bisexual harasser).

26. Oncale v. Sundowner Offshore Servs., 523 U.S. 75, 80 (1998) (stating "harassing conduct need not be motivated by sexual desire to support an inference of discrimination on the basis of sex").

27. Robinson v. Jacksonville Shipyards, Inc., 760 F. Supp. 1486, 1498 (M.D. Fla. 1991). 
which case the harassment would not qualify as sex discrimination. For example, a supervisor may say "sleep with me or you're fired" as a joke. ${ }^{28}$ One can certainly imagine an employer sexually harassing male and female employees for a myriad of reasons other than employee's sex (e.g., because the employee is shy, a "tattletale," advocates feminist beliefs, etc.). Regardless of the sex or sexual orientation of either party, a harasser motivated by such reasons has not sexually harassed the employee "because of such individual's sex."

The fact that not all sexual harassment qualifies as sex discrimination becomes clearer as one moves away from the paradigmatic example of sexual harassment. If one assumes that the harasser is a heterosexual man, ${ }^{29}$ then there are three types of situations that fall outside of the typical sexual harassment case. Namely, the victim might be a heterosexual man, a lesbian or a gay man. In such cases it becomes clearer that not all sexual harassment qualifies as sex discrimination.

\section{The Sexual Harassment of Heterosexual Men}

First consider an example of heterosexual men sexually harassing a heterosexual man. Oncale v. Sundowner Offshore Services ${ }^{30}$ may provide the most familiar example of this situation. Oncale involved allegations that from the start of his employment, Joseph Oncale was barraged with verbal harassment by three men, John Lyons, Danny Pippen and Brandon Johnson. ${ }^{31}$ Their comments ranged from "[y]ou know you got a cute little ass, boy" to threats of rape. ${ }^{32}$ Moreover, the men sexually assaulted Oncale on three occasions. ${ }^{33}$ In the most graphic incident, the men attacked Oncale as he showered. ${ }^{34}$ While Pippen

28. Jansen v. Packaging Corp. of Am., 123 F.3d 490, 567, 569 (1997) (en banc) (Wood, J., joined by Easterbrook \& Rovner, JJ., concurring and dissenting) (stating a supervisor may make constant demands for sex in exchange for job benefits "maybe in jest, maybe not").

29. This assumption should be uncontroversial since most harassers are men. See, e.g., Louise Fitzgerald et al., The Incidence and Dimensions of Sexual Harassment in Academia and the Workplace, $32 \mathrm{~J}$. VocaTIONAL BEHAV. 152 (1988) (finding that 90 to $95 \%$ of sexual harassers are men). If harassers, as a group, mirror the general population, then most of the harassers will be heterosexual as well. Cf. MacKinnon, infra note 31, at 30 (stating "so far as is known, most men who sexually abuse men are heterosexual" and citing MICHAEL SCARCE, MALE ON MALE RAPE: THE HIDdEN TOLl OF STIGMA AND SHAME 17 (1997), which reviewed 14 studies on the sexual abuse of men by men). In contrast, women sexually harass men far less. See MARTHA J. LANGELAN, BACK OFF! HOW TO CONFRONT AND STOP SEXUAL HARASSMENT AND HARASSERS 50-51 (1993) (citing statistics gathered by the National Association of Working Women showing that only one percent of harassment cases involved women harassing men).

30. 523 U.S. 75 (1998).

31. Brief for Petitioner, Oncale v. Sundowner Offshore Servs., 523 U.S. 75 (1998) (No. 96-568); see also Catharine A. MacKinnon, Oncale v. Sundowner Offshore Serv., Inc., 96-568, Amici Curiae Brief in Support of Petitioner, 8 UCLA WOMEN's L.J. 9,13 (1997).

32. Mackinnon, supra note 31 , at 13-14.

33. Id. at 13-14.

34. Id. The first assault occurred on October 25, 1991, while Oncale traveled by boat to another oil platform. Id. Danny Pippen grabbed and pulled Oncale down, ultimately pinning him. Id. Lyons then came over, unzipped his pants "pulled out his penis, and stuck it onto the back of Oncale's head." Id. Lyons and Pippen both laughed as Oncale asked them to stop. Id. The second assault occurred the next day when Brandon Johnson grabbed and forced Oncale to the ground. Id. While Oncale was on the ground, "Lyons pulled his penis out and put it on Oncale's arm." Id. The third assault occurred that same night as Oncale showered. Id. 
pinned Oncale, Lyons forced a bar of soap into his anus and told him "they're fixing to fuck [him]." ${ }^{35}$ The threats continued and Oncale eventually quit because he feared he would be raped. ${ }^{36}$

Under these facts, Joseph Oncale was sexually harassed. ${ }^{37}$ The alleged behavior was sexual, involving claims of sexual assault and other sexual conduct, and it created a hostile work environment. But if one does not define sexual harassment as "a form of sex discrimination" the question remains whether the sexual harassment would have happened "but for" the fact that Oncale was a man. That is, would the men still have harassed Joseph Oncale if he were a woman?

The framework above helps one answer whether such cases qualify as sex discrimination. Although still possible, most men do not have an animus towards men as a group. ${ }^{38}$ And if one assumes, as a fact, that the harassers are heterosexual then one can say that sexual attraction did not motivate the harassment. Whether such behavior qualifies as sex discrimination under the framework above thus turns in most cases on whether gender stereotypes motivated the harassment. For example, if the men harassed Oncale because he acted "too much like a woman" or was "too feminine for a man," then it would qualify as sex discrimination. ${ }^{39}$ On the other hand, if he was sexually harassed for other reasons then it was not sex discrimination.

It is worth emphasizing that under the "but for" framework above, nothing about the sexual harassment inherently makes it different from other Title VII cases. If Oncale was fired rather than sexually harassed for discriminatory reasons, then the employer would still have violated Title VII because the "terms and conditions" of his employment would have been affected. Under this framework, it is the employer's motive that makes an act sex discrimination, not the employer's behavior.

\section{The Sexual Harassment of Lesbians and Gay Men}

The framework above also refines the arguments for and against prohibiting the sexual harassment of lesbians and gay men. Courts have been reluctant to recognize the sexual harassment of gay men and lesbians under Title VII

35. Id. at 13 .

36. Id. Lyons made repeated threats to rape Oncale including: "If I don't get you now, I'll get you later. I'm going to get you. You're going to give it to me ...." and "You told your daddy, huh? Well, it ain't going to do you no good because I'm going to fuck you anyway." Id. at 14 . When asked during a deposition why he left Sundowner, Oncale stated, "I felt that if I didn't leave my job, that I would be raped or forced to have sex." 523 U.S. at 77. Oncale's pink slip stated he "voluntarily left due to sexual harassment and verbal abuse." $I d$.

37. The district court never made a finding of fact because the case settled after the Supreme Court remanded it. See Settlement Reached in Harassment Suit, WASH. TIMES, October 26, 1998, at A9 (discussing the undisclosed settlement).

38. See Craig R. Waldo, Jennifer L. Berdahl \& Louise F. Fitzgerald, Are Men Sexually Harassed? If So, by Whom?, 22 LAW \& HUM. BeHAV. 59, 72 (1998).

39. See Mary Anne Case, Disaggregating Gender from Sex and Sexual Orientation: The Effeminate Man in the Law and Feminist Jurisprudence, 105 YALE L.J. 1, 4 (1995) (arguing that Title VII, correctly applied, protects the effeminate men). 
because the statute only prohibits discrimination "because of such individual's sex" rather than discrimination "because of such individual's sexual orientation" or "because of such individual's sexuality." ${ }^{40}$ Under this logic, Title VII does not prohibit employers from firing employees because they are gay, even though dismissals certainly affect the "terms and conditions" of employment. Similarly, courts have held that Title VII does not prohibit a supervisor from sexually harassing employees because they are gay, even though the harassment may affect their employment. ${ }^{41}$

However, even if one takes this approach to interpreting Title VII, courts must still determine whether the harassment happened "because of such individual's sex." The fact that a plaintiff is gay does not relieve the factfinder of determining whether the harassment happened "because of such individual's sex," because there is nothing about one's sexual orientation that necessarily prevents a claim of sex discrimination.

The easiest example demonstrating this point involves a heterosexual man sexually harassing a lesbian. In such cases, the harassment might still be motivated sexual attraction, gender animus or a gender stereotype. Imagine, for example, a heterosexual employer threatening a gay female employee, "Sleep with me or you're fired." This threat could be motivated in part by the woman's sexual orientation. Yet, it is also clear that such a threat would not be made if the employee were a man and Title VII would prohibit such behavior. ${ }^{42}$

Title VII's focus remains whether the employee would have been treated the same if he or she had been the opposite sex. This point raises a problem in arguing that Title VII does not prohibit discrimination against gay men and lesbians because sexual orientation is defined by reference to an individual's

40. E.g., DeSantis v. Pacific Tel. \& Tel. Co., 608 F.2d 327, 329-330 (9th Cir. 1979); Higgins v. New Balance Athletic Shoe, Inc., 21 F. Supp. 2 d 66 (D. Me. 1998) (holding that harassment that happens because of animus toward plaintiff's sexual orientation is not "because of sex" and plaintiff must offer evidence to show harassment was sex-based under Oncale); see also Chrouser v. DePaul Univ., No. 95 C 7363, 1998 WL 299426 (N.D. Ill. May 20, 1998); Brennan v. Metropolitan Opera Ass'n, No. 95 CIV. 2926 (MBM), 1998 WL 193204 (S.D.N.Y. April 22, 1998); Crawford v. Bank of Am., 181 F.R.D. 363 (N.D. Ill. 1998).

41. E.g., DeSantis, 608 F.2d at 329-30.

42. One might argue that the claim is not actionable because the harassment happened in part "because of" the woman's sexual orientation. However, courts rejected this line of reasoning when they first recognized claims of sexual harassment under Title VII. See, e.g., Bames v. Train, 13 Fair Empl. Prac. Cas. (BNA) 123 (D.D.C. 1974), rev'd sub nom. Bames v. Costle, 561 F.2d 983, 990 (D.C. Cir. 1977) (court of appeals overtuming district court's decision that plaintiff had no cause of action because she "was discriminated against, not because she was a woman, but because she refused to engage in a sexual affair with her supervisor"); Tomkins v. Pub. Serv. Elec. \& Gas Co., 422 F. Supp. 553, 556-57 (D.N.J. 1976) ("It is clear that such a [sexual harassment] claim is simply without the scope of [Title VII]. The abuse of authority by supervisors of either sex for personal purposes is an unhappy and recurrent feature of our social experience. Such conduct is frequently illegal under the penal statutes of the relevant jurisdiction. Such conduct might well give rise to a civil action in tort. It is not, however, sex discrimination within the meaning of Title VII even when the purpose is sexual."), rev'd, 568 F.2d 1044 (3d Cir. 1977). In ovemuling the district court, the courts of appeal maintained that, while other factors may have "caused" the harassment, the central question is whether the plaintiffs would have been treated differently but for their sex. E.g., 568 F.2d at 1047.

To continue the example, one can imagine an animus towards women in the workplace motivating an employer to create a hostile work environment that would be aimed at all women regardless of their sexual orientation. Such behavior would be illegal if it affected the terms and conditions of the employment, regardless of the sexual orientation-or any other characteristic-of the female employee. 
biological sex. For example, firing a male employee because he has intimate or sexual relationships with men would not be taken against a similarly situated female employee who had sexual relationships with men. "But for" his biological sex, the employer would not find his sexual or intimate relationships with men offensive. ${ }^{44}$

Despite the persuasiveness of this argument, and the fact that it is consistent with current discrimination law, ${ }^{45}$ lower courts have rejected this argument. ${ }^{46}$ Courts have instead held that gay men and women must prove they were treated differently than someone of the opposite sex who was also gay. ${ }^{47}$ For instance, a gay man must prove that a lesbian would have been treated differently. ${ }^{48}$

This position has been well critiqued and this article does not take up those arguments. ${ }^{49}$ Instead, it assumes this holding, while emphasizing that this position still recognizes that Title VII protects gay men and lesbians. This is

43. Andrew Koppelman, Why Discrimination Against Lesbians and Gay Men Is Sex Discrimination, 69 N.Y.U. L. REv. 197, 208 (1994); Samuel A. Marcosson, Harassment on the Basis of Sexual Orientation: A Claim of Sex Discrimination Under Title VII, 81 GEO. L.J. 1, 4-5 (1992).

44. Discrimination against gay men and lesbians easily fits the "but for" definition of sex discrimination because in the United States a heterosexual is defined as someone who sexually prefers people of the opposite sex and a homosexual is defined as someone who prefers people of the same sex. These definitions, however, are not universally accepted. In Latin America, "homosexual" refers only to a man who takes the passive role, letting himself be penetrated. In contrast, "heterosexual" refers to a man who takes the active role, with either women or men, and usually acts macho. Snow Whites and Snake Charmers, ECONOMIST, Dec. 18-30, 1999, at 82 (discussing the definition and meaning of heterosexual and homosexual in traditional Latin America).

45. For example, in Dothand v. Rawlinson, 433 U.S. 321 (1977), the Supreme Court heard a case in which prisons required guards to be the same sex as inmates. The Court held that this "explicitly discriminates against women on the basis of their sex." Id. at 332. Moreover, the policy discriminated against the employees because of their sex, even though "[b]y its terms [the law] applies to contact positions in both male and female institutions." Id. at $332 \mathrm{n} .16$. The fact that the law applied "equally" to men and women (for example, men could not serve in female prisons) did not shield it from a claim of discrimination. Simply put, the policy was discriminatory because "but for" their sex, women could serve as prison guards in the male prison. The Court, however, held that the policy was legal because, while constituting sex discrimination, it qualified as bona fide occupational qualification under 703(e) of Title VII, 42 U.S.C. $\$ 2000 \mathrm{e}-2$ (e) (1994). Id. at 336-337.

This analysis of "same-sex" policies qualifying as sex discrimination applies in other areas as well, such as nursing homes and dormitories. E.g., Jones v. Hinds Gen. Hosp., 666 F. Supp. 933 (S..D. Miss. 1987) (nursing homes); AFSCME v. Mich. Council, 635 F. Supp. 1010 (E..D. Mich. 1986) (nursing homes); Hemandez v. Univ. of St. Thomas, 793 F. Supp. 214 (D. Minn. 1992) (dormitory custodians). In each, the court found that the "same-sex" discrimination was sex discrimination; the only issue was whether it qualified for the BFOQ exception. For background and a recent analysis of case law on sex discriminatory policies and the "privacy BFOQ", see Jillian B. Berman, Comment, Defining the "Essence of the Business": An Analysis of Title VII's Privacy BFOQ after Johnson Controls, 67 U. CHI. L. REV. 749, 752-762 (2000).

Outside the Title VII context, state courts have begun to recognize that prohibiting homosexual men and lesbians from marrying also qualifies as sex discrimination, and thus the prohibition is subject to heightened scrutiny under the state constitution. Baehr v. Lewin, 852 P.2d 44 (Haw. 1993) (plurality opinion); Brause v. Bureau of Vital Statistics, No. 3AN-95-6562 Cl, 1998 WL 88743 at *6 (Alaska Super. Feb. 27, 1998) ("That this is a sex-based classification can readily be demonstrated . . . if twins, one male and one female, both wished to marry a woman and otherwise met all of the [state's] requirements, only gender prevents the twin sister from marrying under the present law. Sex-based classification can hardly be more obvious.").

46. E.g., DeSantis v. Pacific Tel. \& Tel. Co., 608 F.2d 327 (9th Cir. 1979).

47. E.g., Dillon v. Frank, 952 F.2d 403 (6th Cir. 1992) (arguing that the plaintiff failed to prove "discrimination because of sex" because "he has not argued that a lesbian would have been accepted at the Center. ... Without such a showing, his claim to have been discriminated against because he is male cannot succeed.").

48. Id.

49. Koppelman, supra note 43; Marcosson, supra note 43. 
important because in the upcoming years courts will have to fashion a doctrine that treats this test seriously. It is to that question that this article now turns.

\section{Prohibiting SeXual Harassment as a RULE of AdJudication}

Prohibiting sexual harassment, as such, has operated as a bright-line rule for judges and juries to apply to Title VII cases. In the context of male-female harassment, courts have held employers liable if the factfinder found that the employee was harassed in a way that (1) affected the "terms and conditions" of the employment and (2) was "sexual in nature." inquiry into whether the sexual harassment happened "because of such individual's sex." ${ }^{\text {"5l }}$ A major criticism of this doctrine is that it operates as an exception to Title VII. ${ }^{52}$ Commentators have argued that courts have not treated Title VII's discrimination element seriously but avoided the "because of such individual's sex" question by holding that sexual harassment, as such, is prohibited.

One can view the choice between prohibiting sexual harassment per se or only sexual harassment that happens "because of such individual's sex" as a dispute over whether to adopt a general rule to decide individual cases or to take a more rule-free, case-by-case approach - a debate that takes place in every area of law. ${ }^{53}$ On the one hand, there is the argument that courts should simply prohibit all sexual harassment. On the other hand, there is the argument that courts should make more individualized judgments, prohibiting only sexual harassment that qualifies as sex discrimination. As this part shows, framing the debate this way refines the arguments for and against prohibiting sexual harassment under Title VII.

This part proceeds in three sections. The first section begins with the stylized notion that people often adopt rules because they minimize the sum of error costs and decision costs. One can apply this model to a variety of contexts, including the way judges decide cases. The second section builds on this concept by discussing the fact that other values influence judges' decisions. For example, the legal system also seeks to increase predictability for those affected by the law. This section uses the paradigmatic example of a heterosexual man sexually harassing a heterosexual woman to show why courts should prohibit sexual harassment, while recognizing that the same arguments apply to prohibiting the sexual harassment of heterosexual men, lesbians and gay men. The third section argues that if courts continue to extend such categorical protection to womenas they already have-then, for constitutional reasons of equal protection, they must extend it to all plaintiffs regardless of their sex or sexual orientation.

50. See supra note 7 (discussing courts' standard approach to deciding sexual harassment cases in the male-female context).

51. See supra note 7.

52. Willborn, supra note 4, at 677 .

53. See Cass R. Sunstein, Problems with Rules, 83 CALIF. L. REv. 953, 957 (1995). 


\section{A. Examining the "Error" Costs and "Decision" Costs}

It is a conventional idea that people try to make good decisions at low costs and in such a way that maximizes the net benefit of the decision. ${ }^{54}$ In all walks of life, people want to make the best choice, but they also do not want to spend too much time and effort deciding. ${ }^{55}$ As a result, people adopt various strategies to help them make decisions. For example, people often apply a "rule of thumb" or a presumption to make a decision. Even though such strategies will err on particular occasions, one of their central virtues is they lower the costs of making the decision.

One can apply this conception of decision-making across many settings. Briefly consider how people decide whom to vote for or how schools decide which students to admit. Some people vote Democrat "across the board" and many law schools use a "GPA-LSAT" formula to admit or reject students. Of course, such strategies make mistakes, but they also significantly lower the costs of making the decision.

Judges are in the business of making decisions, and one can frame their decisions in these terms. That is, judges also attempt to make "good decisions" at "low costs" and this may involve adopting rules or irrebutable presumptions to decide individual cases. Indeed, one can find judges adopting rules in all areas of law. ${ }^{56}$

It is important to note, though, that one cannot argue for the adoption of rules, or any other decision strategy, in the abstract. General rules can produce enormous costs for few benefits or few costs for large benefits; at some level one must be weighed against the other. For example, good doctors typically do not use rigid rules to treat patients, in part because the cost of making an error (e.g., misdiagnosis) is high. $^{57}$ In other contexts, rules are more acceptable. Bureaucracies-reviled for their rigidity-often adopt rules because they must repeatedly make similar decisions. The cumulative cost of deciding on an individual level would be too high. The arguments for adopting a rule will depend on the context and rest on the costs and benefits of that approach.

\section{Error Costs}

What does it mean for a judge to make a "good" or "bad" decision in the context of Title VII? For those who argue that Title VII's crucial inquiry is whether an employer treated members of one sex differently from members of

54. E.g., GARY BECKER, ACCOUNTING FOR TASTES (1996).

55. See George J. Stigler, The Economics of Information, 69 J. POL. ECON. 213 (1961) (arguing that every decision-maker must recognize the point at which information-gathering should stop and a decision should be made).

56. Sunstein, supra note 53 , at $\mathbf{1 0 2 3}$ (outlining the wide-range of rules adopted in the law).

57. See Kathryn M. Hunter, Doctors' Stories: The Narrative Structure of Medical KNOWLEDGE (1991). 
the other sex, a judge who holds an employer liable makes a "good decision" if, in fact, the employee would not have suffered the adverse employment action "but for" his or her sex. In contrast, the judge errs if the employer is held liable and the adverse employment decision did not turn on the employee's sex but happened "because of" something else.

One can certainly contest this definition of error because it relies on a normative theory of interpreting Title VII. Specifically, it interprets "because of such individual's sex" to mean the differential treatment of men and women. Indeed, this is precisely where the debate over sexual harassment has been focused. Those theories that argue that sexual harassment is "a form" of sex discrimination are, in essence, arguing that courts do not err by prohibiting it. ${ }^{58}$ Nonetheless, it should be recognized that this article assumes sex discrimination means "treating men and women differently." Once one adopts this definition, then one can determine when a decision errs.

The framework outlined above helps explain the error in prohibiting all sexual harassment. This approach yields the correct result when individual cases of sexual harassment are motivated by sexual desire, gender animus or gender stereotypes but errs to the degree that other reasons motivate such behavior. This points us towards an important factual question: How many cases of sexual harassment happen "because of such individual's sex" and how many happen for another reason?

For several reasons, existing studies on sexual harassment are severely limited in the help they provide to answer this question. ${ }^{59}$ First, the majority of studies have focused on the sexual harassment of women by men. ${ }^{60}$ Thus, it is hard to make comparative statements. Second, existing studies have been conducted from a social science perspective rather than a legal one. One problem with this is that one cannot always conclude that what qualifies as "sexual harassment" in a study meets the legal definition. For example, the behavior categorized as sexual harassment might not be "severe or pervasive" enough to alter the terms and conditions of the employment. ${ }^{61}$ Third, such studies have mostly concentrated on the victims of sexual harassment and the effects of the harassment, rather than on the perpetrator. ${ }^{62}$ No study has examined the sexual orientation of those who harass or the motivations behind their behavior. Nor has any study detailed the sexual orientation of both the harasser and the victim at the same time.

58. See supra note 2.

59. For a brief summary of existing literature, see Waldo et al., supra note 38 , at 60 . For a more extensive summary, see William E. Foote \& Jane Goodman-Delahunty, Same-Sex Harassment: Implications of the Oncale Decision for Forensic Evaluation of Plaintiffs, 17 BEHAV. SCI. \& L. 123 (1999).

60. See Waldo et al., supra note 38 , at 60 ("Most research has examined the sexual harassment of women by men, reflecting the overwhelming majority of actual experiences.").

61. Likewise, some studies label behavior as "sexual harassment" but do not differentiate between sexual and non-sexual conduct. E.g., Waldo et al., supra note 38. From a legal perspective, this difference is critical. See supra note 23 (providing EEOC's definition of sexual harassment).

62. For example, studies focus on the impact of the sexual harassment or the number of cases in a given population. See Appendix A for a summary of the studies. 
Nonetheless, three general points emerge from existing research and each challenges conventional assumptions about sexual harassment. The first point is that a substantial proportion of men have been sexually harassed at work. A recent study indicates that almost half of men have been harassed at work in some way. ${ }^{63}$ For example, in one study $29 \%$ of men reported experiencing unwanted sexual attention and $44.1 \%$ experienced "lewd and offensive" comments. Significantly, men are most often harassed by other men. ${ }^{64}$ Such facts are important because they undermine the assumption that when a man sexually harasses a woman it happens "because of her sex." Hence, one could argue that sexual harassment in the male-female context does not always qualify as sex discrimination.

The facts of Oncale help demonstrate this. It is conceivable that the men on the oil rig sexually harassed Joseph Oncale for reasons unrelated to his sex; that is, one can imagine he still would have been sexually harassed if he had been female. For those who interpret Title VII to mean that men and women must be treated the same at work, this conclusion is akin to saying that the men harassed Oncale "because of" something besides his sex. To borrow from a Justice's question in Oncale's oral argument, one can imagine that the men sexually harassed him because he was a "fat slob" or had "crooked eyes." Under this logic, the employer should not be held liable.

But an often-missed point in this argument is that a similarly situated woman - a woman who was also "a fat slob" or had "crooked eyes"-would not have been sexually harassed "because of her sex" either. Thus, a woman in Joseph Oncale's place would not have a claim either. In short, the fact that men sexually harass other men in substantial numbers weighs against the assumption that men always sexually harass women "because of their sex." In this light, it is quite striking that courts have presumed that all sexual harassment aimed at women would not have happened if they were men.

The second point is that a substantial proportion of sexual harassment aimed at men may still qualify as sex discrimination. For example, recent research indicates that perhaps as much as $11 \%$ of men in the workforce are harassed for reasons related to gender stereotypes. ${ }^{66}$ Again, the harassment is most often by other men. For example, men harass other men if they do traditionally female activities such as housework or leaving work for child care. ${ }^{67}$ Such evidence

63. Waldo et al., supra note 38 , at 68 .

64. Id. at 69 .

65. Transcript of Oral Argument at 13, Oncale v. Sundowner Offshore Servs., 523 U.S. 75 (1998) (No. 96-568), available in 1997 WL 751912 (Dec. 3, 1997) (asking, "Suppose he had been hazed in some other fashion. I mean, just as obnoxious, but just not-you know, nothing to do with genitals or anything else. They just said, you know, you're a fat slob. Your eyes are crooked. And, you know, they just made life miserable. The same, but-just as obnoxious.").

66. Waldo et al., supra note 38, at 72; see also U.S. MERIT SYS. PROT. BD., SEXUAL HARASSMENT IN THE Federal Workplace: Trends, Progress, Continuing Challenges 14 (1994) (stating that 14\% of men reported experiencing "unwanted sexual behavior" in the previous two years and $35 \%$ of the harassers were men).

67. Waldo et al., supra note 37 , at 68 . 
supports the conclusion that some men, perhaps a substantial number, are sexually harassed "because of their sex."

The third point challenges the assumption that harassment aimed at a gay man would have also been aimed at him if he were a lesbian and vice versa. A number of studies indicate that there are gender differences in rates of victimization against gay men and lesbians. ${ }^{68}$ On the whole, gay men experience greater levels of anti-gay verbal harassment, threats, victimization and most types of physical violence and intimidation. ${ }^{69}$ Most important, gay men generally experience greater levels of violent sexual harassment than lesbians. ${ }^{70}$ While this point is tenuous, it indicates that in some cases gay men would not be sexually harassed if they were lesbians. Indeed, it is conceivable that some men feel more threatened by gay men than by lesbians; gay men may pose more of a challenge to those men's self-concept of masculinity than do lesbians. ${ }^{71}$ In that case, harassment of gay men qualifies as sex discrimination under the test given by a majority of courts: If they were lesbians, they would not be harassed.

Moreover, there is no reason to think that a person's sexual orientation is the only motive for harassment in every case. Consider the research that shows gay men who describe themselves as "feminine" are twice as likely as other gay men to have experienced "gay bashing." 72 This indicates that gay men are not necessarily sexually harassed "because of" their sexual orientation but because of the gender stereotype that men should not act feminine. At the same time, one might reasonably conclude that lesbians face harassment from men motivated by different reasons, such as sexual attraction and gender animus. ${ }^{73}$ When that is the case, they should have a claim also. The simple point is that a court adjudicating Title VII claims cannot simply conclude that harassment aimed at gay men and lesbians can never qualify as "sex discrimination" under current law. Rather, a court's duty in adjudicating such cases is more complicated and subtle than case law currently reflects.

To be clear, these points are rather rough generalizations at best. They do not, by themselves, compel the conclusion that courts should prohibit all sexual harassment, and they leave many questions unanswered. Nonetheless, the claim

68. Kevin Berrill, Anti-Gay Violence and Victimization in the United States: An Overview, in HaTE Crimes, Confronting Violence Against lesbians and Gay Men 19, 25 (Gregory M. Herek \& Kevin T. Berrill eds., 1992).

69. Id.

70. Kevin T. Berrill, Anti-Gay Violence and Victimization in the United States: An Overview, 5 J. INTERPERSONAL VIOLENCE, 274, 280 (1990); Kevin T. Berrill, supra note 68, at 19-46.

71. Benjamin B. Wolman \& John MONey, HandBook of Human Sexuality 305 (1993) (discussing the "overwhelming anxiety" heterosexual men may feel when placed in a situation that causes them to question their own heterosexuality, such as being confronted by a gay man). This is in fact frequently asserted by heterosexual men who kill gay men. MiCHAEl SCARCE, MALE ON MALE RAPE: THE HidDEN TOLL OF STIGMA AND SHAME 212-13 (1997) (discussing the common assertion of heterosexual men who kill gay men that the victim made a homosexual advance at them, sending them into a "homosexual panic" during which the victim was killed).

72. Deaux \& LaFrance, supra note 19 , at 793.

73. Beatrice von Schulthess, Violence in the Streets: Anti-Lesbian Assault and Harassment in San Francisco, in HATE CRIMES, CONFRONTING VIOLENCE AGAINST LESBIANS AND GAY MEN, supra note 68, at 70. (stating that attacks on lesbians often began as anti-woman and then have an added anti-lesbian dimension). 
is that any court using this interpretation-that Title VII prohibits differential treatment of men and women - should be concerned about how many cases of sexual harassment are motivated "because of such individual's sex" and how many are motivated by other reasons. Moreover, the existing empirical research on sexual harassment should at least serve as a background for the courts' opinions and the debate over sexual harassment.

From these general points, two conclusions follow. First, the most one can say is that in every variation of sexual harassment, some--but not all-of it qualifies as sexual discrimination under the "but for" approach. For example, current research cannot support the assumption that all or almost all the sexual harassment of women by men happens "because of their sex." Thus, prohibiting all sexual harassment, even in the paradigmatic case of harassment, sweeps too broadly. At the same time, it is incorrect to conclude that same-sex sexual harassment or the sexual harassment of gay men and women cannot qualify as sex discrimination.

The second conclusion is that studies focusing on sexual harassment from a legal perspective would improve the current debate significantly. Such studies should also concentrate on giving a more detailed account of the sexual orientation and sex of the perpetrators and victims. Most important, the studies should focus on harassers' motivations and whether they would have treated a similar person of the opposite sex differently.

\section{Decision Costs}

A major reason for courts to prohibit all sexual harassment is that it is much easier-or less costly in terms of time and effort- to determine whether a plaintiff has been sexually harassed than to separate out those cases that happen "because of such individual's sex" from those that happen for other reasons. Consider the following example:

James River Corporation hired Ann Goluzsek as a mechanic. She had never married, nor lived anywhere but her mother's home. According to Goluszek's psychiatrist, she had an "unsophisticated background" and led an "isolated existence" with "little or no sexual experience." She also "blushed easily" and was sensitive to comments pertaining to sex.

Shortly after Goluzsek started working, a number of machine operators asked her why she was not married, and joked that employees had to be married to work there. They also told her to go out with certain coworkers, because they would "fuck" her. When she had trouble fixing a machine, the same operators said they would call her "daddy" to help, referring to the supervisor. On a number of occasions, while Goluzsek worked on a ladder, 
employees driving forklifts threatened to knock her off. When a supervisor reprimanded Goluzsek for poor performance, she requested a meeting with the plant manager. She complained about both the manager and the danger the forklift drivers presented to her.

When the company transferred Goluzsek to the night shift, her co-workers repeatedly asked her if she had gotten any "pussy" or had oral sex, showed her pictures of nude women, told her they would get her "fucked," and accused her of being gay or bisexual. The employers also poked her in the buttocks with a stick and talked to her about "butt fucking" in the ass. The behavior continued, and Goluzsek eventually filed a complaint. ${ }^{74}$

The costs of deciding sexual harassment cases involve both the costs of deciding the individual case and the cumulative cost of deciding the class of cases. On the individual level, the costs of determining whether this harassment happened because of Goluszek's sex or because of some other reason could be quite significant. Based on these facts, one could argue that the harassment was motivated by gender animus, sexual attraction or a gender stereotype. However, one could also argue that the harassment happened because the victim was unusually shy, was sexually inexperienced, lived with her mother, came from an unsophisticated background or complained about the manager. Determining the true motivation would not be a simple matter.

One must also consider the incentives a case-by-case approach would give to the litigants. Once in court, the threat of losing the lawsuit gives defendants an incentive to argue that the harassment took place for any reason other than the plaintiff's sex. One can imagine defendants raising innumerable defenses in the hypothetical above (e.g., she was harassed not "because of" her sex, but because she was unusually shy, sexually inexperienced, etc.). Even in the most meritorious claims, litigating the issue would take a good amount of time and energy.

At the same time, the costs to a court would be cumulative. Given that decision-makers are more likely to adopt rules if they must make many similar decisions, ${ }^{75}$ it is significant that courts, as well as others in the legal system, must frequently decide sexual harassment cases. For example, the EEOC, the government agency charged with enforcing Title VIII, ${ }^{76}$ has received around 15,500 complaints a year for several years now, $50 \%$ more than the number

74. This hypothetical generally follows the facts of Goluszek v. Smith, 697 F. Supp. 1452 (N.D. Ill. 1988), in which the plaintiff was male.

75. Louis Kaplow, Rules Versus Standards: An Economic Analysis, 42 DUKE L.J. 557, 563 (1992); Sunstein, supra note 53, at 1015 ("When numerous decisions of the same general class must be made, the inaccurate fit of a rule becomes far more tolerable.").

76. 29 C.F.R. § 1604.11(a) (1997). 
decided in $1992 .^{77}$ Just as important is the increase in cases in which the EEOC has found reasonable cause for viable claims of sexual harassment. In 1992, the EEOC issued 285 reasonable cause determinations, or $3.8 \%$ of the total charges filed. In 1999, it issued 1,180 reasonable cause determinations, or $7.1 \%$ of the total charges filed. ${ }^{78}$ As one commentator noted, "Sexual harassment law is booming .... In coming years, harassment litigation will occupy more and more attention from courts and employers." 79

The clear advantage of prohibiting all sexual harassment is it substantially lowers the costs of adjudication. Courts simply need to decide whether something qualifies as "sexual harassment" and if it affected the terms and conditions of employment instead of attempting to separate out those cases that were motivated by the litigant's sex from those that were motivated by other reasons. Although one cannot easily quantify how much this lowers the cost of making such decisions, it does appear significant. In this way, one can understand why courts have not engaged in a case-by-case analysis of causation for the last decade when men have sexually harassed women. ${ }^{80}$

\section{B. Other Values Promoted by a Per Se Rule}

Thus far, the article's argument is simple: Prohibiting all harassment involving sexual conduct is overinclusive but it significantly lowers the costs of adjudicating cases. This section points to two other values served by bright-line rules. First, they reduces arbitrary and biased decision-making. Second, rules promote more predictable outcomes for those affected by the law. Rules have these virtues because, by definition, they attempt to make the necessary judgments in advance of the actual cases. ${ }^{81}$

Again, reconsider the Goluzsek hypothetical presented above. Did the men sexually harass her "because of her sex" or "because of" some other reason such as the fact that she was not married, had little sexual experience, and lived with her mother? Would they have treated her the same if she had been a man? It is very difficult to answer these questions accurately in each case. The problem is not that one cannot imagine examples in which the harassment was motivated by reasons other than the person's sex. The problem is that in the real world one cannot separate those cases from those that were motivated by the employee's sex in a precise way.

77. EEOC, Sexual Harassment Statistics FY 1992-FY 1999, at http://urww.eeoc.gov/stats/harass.html (last visited January 15, 2001) (reporting that in 1992, 10,532 filings were made with the EEOC, compared to 15,222 filings in 1999.).

78. Id.

79. Mark M. Hager, Harassment and Constitutional Tort: The Other Jurisprudence, 16 HOFSTRA LAB. \& EMP. L.J. 279, 279 (1999).

80. See supra note 7 (describing courts' per se prohibition of sexual harassment).

81. See Sunstein, supra note 53, at 961 ("Rules are largely defined by the ex ante character of law. By the aspiration to a system of rules, I therefore mean to refer to something very simple: approaches to law that try to make most or nearly all legal judgments under the governing legal provision in advance of actual cases."). 
A case-by-case or more rule-free approach increases the chances that the case will turn on arbitrary factors. ${ }^{82}$ In cases like the hypothetical, any decision will reflect a good amount of guesswork as to whether the harassment qualified as sex discrimination. At worst, such decisions would be biased against particular litigants. For example, litigants might lose because they are in some way not normal (e.g., "abnormally shy"). An advantage to prohibiting sexual harassment is this approach treats claims of sexual harassment the same because the case depends only on whether the alleged behavior qualifies as sexual harassment. In this way, prohibiting sexual harassment acts impartially by focusing on the conduct alone.

Prohibiting all sexual harassment also increases the predictability covered by the law. Employees and employers must deal with many of the same problems judges face. They must decide whether an employee has violated the law and design procedures to handle problems that arise. Without a rule-like approach, it will frequently be unclear whether the employer has violated the law or-more precisely - whether a court would hold an employer liable for certain behavior. Given that it is often more important to know what the law is than to have a particular law, prohibiting all sexual harassment is preferable to a case-by-case approach. ${ }^{83}$ In sum, it would give employees and employers a better sense of what the law prohibits in the workplace.

\section{Equal Protection: Tying it together}

There is another, perhaps more important, reason why courts should use a conduct-based approach: It avoids violating the Constitution's mandate of equal protection. Under the Fourteenth Amendment, the government-which includes federal courts ${ }^{84}$ - may not deny "any person ... equal protection of the laws." 85 As it applies to sexual harassment doctrine, this raises two problems for courts if they distinguish between plaintiffs based on their sex or sexual orientation.

The first problem is that the Fourteenth Amendment, as interpreted by the Supreme Court, requires government actors to treat men and women the same unless "an exceedingly persuasive" justification for the differential treatment can

82. Id. at 974 .

83. See Antonin Scalia, The Rule of Law as a Law of Rules, 56 U. CHI. L. REv. 1175, 1179 (1989). ("As laws have become more numerous, and as people have become increasingly ready to punish their adversaries in the courts, we can less and less afford protracted uncertainty regarding what the law may mean. Predictability, or as Llewellyn put it, 'reckonability,' is a needful characteristic of any law worthy of the name. There are times when even a bad rule is better than no rule at all.").

84. Palmore v. Sidoti, 466 U.S. 429 (1984) (court's child custody order subject to demands of Fourteenth Amendment); New York Times v. Sullivan, 376 U.S. 254 (1964) (judicial enforcement of an individual's defamation claim held subject to the Fourteenth Amendment and, through it, the First Amendment); Moose Lodge No. 107 v. Irvis, 407 U.S. 163, 179 (1972) ("State action. . . may emanate from rulings of administrative and regulatory agencies as well as from legislative or judicial action."); see also J. NoWAK \& R. ROTUNDA, CONSTITUTIONAL LAW 452 (1991) ("When a legislature, executive officer, or court takes some official action against an individual, that action is subjected to review under the Constitution, for the official act of any governmental agency is direct governmental action and therefore subject to the restraints of the Constitution.").

85. U.S. CONST. amend. XIV, §1. 
be provided. ${ }^{86}$ As a result, courts must generally interpret statutes in such a way that men and women are accorded similar relief. Unless courts can meet this burden, they may not interpret Title VII to prohibit the sexual harassment of women at work under Title VII without also prohibiting the same conduct aimed at men.

Under the facts of the Goluzsek hypothetical above, a female plaintiff would have a claim if the harassment affected the terms and conditions of work. Courts would presume that conduct happened "because of her sex." ${ }^{17}$ Once courts extend this presumption to women who are sexually harassed, however, the Constitution requires that they extend the presumption to men. This is particularly true because some men and women will be similarly situated with regard to the discriminatory motive ${ }^{88}$ For example, regardless of the victim's sex, the harassment might be motivated by gender stereotypes-in which case both men and women should have a claim. Likewise, men and women are similarly situated whenever a motive other than their sex motivates the harassment.

This is not to deny that women and men-as groups-may be differently situated. Women may be sexually harassed much more often because of their sex than are men. But the fact that women and men are on average different does not allow the courts to treat all women and all men differently under current doctrine. Even though significant differences may exist between men and women as groups, the government must treat every individual the same regardless of that person's sex. Under existing case law, the Constitution does not allow courts to categorically assume that the certain types of harassment happened "because of such individual's sex" when the plaintiff is a woman, while requiring men in the same situation to prove it. ${ }^{89}$

The second constitutional problem involves treating gay men and lesbians differently than heterosexual men and women. Before analyzing that issue, however, it is to important to underline a point that follows from the analysis above: If courts presume that the sexual harassment of lesbians violates Title VII, they must grant the same presumption to gay men. This is important because in the vast majority of cases involving men sexually harassing women, courts have not even inquired into the plaintiff's sexual orientation. Indeed, under the future doctrine of sexual harassment sketched by the Supreme Court in

86. United States v. Virginia, 518 U.S. $515,532-33$ (1996).

87. See Part III.A for a summary of current sexual harassment doctrine under Oncale.

88. See United States v. Virginia, 518 U.S. 515, 520 (1996) (emphasizing that there was nothing about military school that made it inherently unsuitable to women generally and that some women could perform well under the school's "adversative" system); see also id. at 573 (Scalia, J., dissenting) (arguing that under the majority's test, one would have to find VMI's admissions policy unconstitutional if there existed "a single woman ... willing and able to undertake VMI's program").

89. See Wengler v. Druggists Mut. Ins. Co., 446 U.S. 142, 152-53 (1980) (holding that the state must either grant assumption of proof to all males because they granted it to all females, or eliminate it for females and take a case-by-case approach); see also Lehman, supra note 13, at 150. 
Oncale in 1998, the fact that a plaintiff is a lesbian plays no role in deciding whether the employer violated Title VII. ${ }^{90}$

However, this argument does not resolve whether a court could treat both gay men and lesbians differently than heterosexual men and women. The answer is ambiguous because equal protection doctrine as it applies to gay men and lesbians has just begun to develop. The leading case is Romer v. Evans, ${ }^{91}$ the first and only case in which the Supreme Court applied the Equal Protection Clause to government action that discriminated against gay men and lesbians. In Romer, the Court held that a Colorado constitutional amendment (Amendment 2) prohibiting all action at any level of government to protect homosexuals from sexual orientation discrimination violated the Fourteenth Amendment.

The Court gave two reasons for striking down Amendment 2. First, it held that the amendment was "at once too narrow and too broad" because it "identifies persons by a single trait and then denies them protection across the board." classification and any legitimate purpose. Second, the Court said "the amendment seems inexplicable by anything but animus toward the class it affects." ${ }^{93}$ By making "a general announcement that gays and lesbians shall not have any particular protections from the law, [it] inflicts on them immediate, continuing, and real injuries that outrun and belie any legitimate justifications that may be claimed for it." ${ }^{194}$ Since Amendment 2 was far too broad to be justified by reference to any of the state's purposes, it failed as "a status-based enactment ... [ []]t is a classification of persons undertaken for its own sake." ${ }^{.95}$

Of course, differences exist between Amendment 2 and courts' interpreting Title VII so that gay men and lesbians are not granted a presumption of sex discrimination when they are sexually harassed. The latter appears small in scope when measured against a state constitutional amendment. Such an interpretation would affect only the rights of gay men and lesbians under a federal statute, might not be considered overly broad, and does not seem to be based solely in animus or "divorced from any factual context." Instead it seems to reflect some notion that sexual harassment aimed at gay men and lesbians qualifies less frequently as "discrimination because of such individual's sex" than does sexual harassment aimed at heterosexual men and women.

Such an interpretation of Romer has problems, though. Romer itself avoided any bold doctrinal or theoretical pronouncements. Thus, one could argue that the decision represents more of the "floor" of the Equal Protection Clause and demonstrates what is not acceptable, rather than a ceiling for what is. Moreover, granting presumptions to heterosexual men and women still classifies plaintiffs

90. See Part III.A (summarizing current sexual harassment doctrine after Oncale).

91. 517 U.S. 620 (1996).

92. Id. at 633 .

93. Id. at 632 .

94. Id. at 635 .

95. Id. at 635 .

96. Id. at 635 . 
by their sexual orientation and then affords them less protection if they are not heterosexual. Although not done for "its own sake," it is still "a status-based classification" that is especially noticeable because it would be the only characteristic on which a presumption of discrimination would be denied. For example, courts would not examine more closely whether a case really qualified as sex discrimination if the person was unusually shy, a feminist, "a fat slob," unmarried or had any other characteristic that might motivate the harassment. In this way, there is a sense in which treating people's Title VII rights differently based on their sexual orientation reflects a broader societal prejudice, which by itself could not serve as the sole basis for the differential treatment. ${ }^{97}$

The best argument, however, is not that granting plaintiffs different presumptions on the basis of their sexual orientation would be unconstitutional. Reasonable arguments can be made either way under current doctrine. The best argument is that courts are interpreting an act of Congress, and in so doing they should avoid substantial constitutional questions, a familiar principle of interpretation. ${ }^{98}$ It may, or may not, be constitutional for Congress to pass a statute that treated gay men and lesbians differently by giving them higher burdens of proof under Title VII. But courts should not interpret Title VII in a way that raises constitutional issues unless Congress has clearly spoken on the issue. ${ }^{99}$

In sum, courts should utilize a conduct-based approach because, even though it is overinclusive, it significantly lowers litigation costs, reduces arbitrary and biased decisions and promotes predictability. Moreover, courts should not distinguish between plaintiffs based on their sex or sexual orientation, because even if not unconstitutional, such an interpretation raises serious constitutional questions that courts should avoid.

\section{When CONDUCT PROVES CAUSATION: NeW DOCTRINE, OLD DOCTRINE, SAME DOCTRINE}

This part situates this article's argument into a broader judicial context. First, it explains how this argument works under existing sexual harassment case law.

97. See id. at $634-35$.

98. See Edward J. DeBartolo Corp. v. Fla. Gulf Coast Bldg. \& Constr. Trades Council, 485 U.S. 568, 575 (1988) ("Where an otherwise acceptable construction of a statute would raise serious constitutional problems, the Court will construe the statute to avoid such problems unless such construction is plainly contrary to the intent of Congress."); see also Kent v. Dulles, 357 U.S. 116, 128-30 (1958) (construing statute to avoid constitutional questions); NLRB v. Catholic Bishop, 440 U.S. 490, 500-01, 504-07 (1979) (same); Pub. Citizen v. United States Dep't of Justice, 491 U.S. 440, 466 (1989) (describing the cannon of avoiding raising constitutional issues as an "axiom of statutory interpretation").

99. One might also argue that courts should avoid the constitutional issue because the current test for equal protection relies on the government's putting forth facts, to some degree, that show the classification has a relationship to serving a legitimate interest. See Romer, 517 U.S. at 632 . When compared to Congress, however, courts are deficient in their ability to make such findings (e.g., courts cannot order an empirical study to be performed). As the discussion in Part II on existing research demonstrates, there are many questions still open as to how much harassment aimed at gay men and lesbians qualifies as sex discrimination. As a result, it may be better for courts to be cautious and not classify plaintiffs by their sexual orientation. 
Second, it shows how this approach fits under the framework of Title VII. Finally, it examines other areas in which courts must answer "because of" or "but for" questions and shows that courts frequently use bright-line rules even though they are overinclusive.

\section{A. New Doctrine: Sexual harassment after Oncale}

In Oncale v. Sundowner Offshore Services ${ }^{100}$ the Supreme Court held that Joseph Oncale was not barred, as a matter of law, from suing his employer for sexual harassment because the harassers were also men. That is, plaintiffs may sue for sexual harassment under Title VII regardless their sex. In dicta, the Court very briefly outlined three evidentiary routes plaintiffs might take to prove Title VII's causation requirement. ${ }^{101}$ The first evidentiary route involves the trier of fact inferring discrimination based on the sexual proposals and the harasser's sexual orientation. For example, a female plaintiff might show that "explicit and implicit proposals of sexual activity" were made by a heterosexual man. Likewise, male plaintiffs may satisfy the requirement by proving the harasser is homosexual. ${ }^{102}$

However, the Court stated that "harassing conduct need not be motivated by sexual desire to support an inference of discrimination on the basis of sex," and thus other evidentiary routes were possible. To prove this point, the Court gave a one-sentence example. "A trier of fact might reasonably find such discrimination, for example, if a female victim is harassed in such sex-specific and derogatory terms by another woman as to make it clear that the harasser is motivated by general hostility to the presence of women in the workplace," 104 the Court explained. For this second evidentiary route, factfinders presumably look at the conduct regardless of the harasser's sexual orientation. The Court then concluded by stating a "plaintiff may also, of course, offer direct comparative evidence about how the alleged harasser treated members of both sexes in a mixed-sex workplace." 105

This article's basic suggestion is that courts interpret the three evidentiary routes to represent, respectively, the three types of harassment claims litigants could bring before Oncale: quid pro quo, hostile work environment and nonsexual harassment. Courts would thus take two crucial steps in every harassment case. The first step would determine whether the harasser's conduct altered the "terms and conditions" of work. ${ }^{106}$ Under this analysis, the harassment would

100. 523 U.S. 75 (1998).

101. Id. at $80-81$.

102. Id. at 80 .

103. Id.

104. Id.

105. Id. at $80-81$

106. The unwelcomeness requirement that is part of the standard approach to sexual harassment, see supra note 7, would presumably be considered in this step. See Reed v. Shepard, 939 F.2d 484, 491 (7th Cir. 1991) (considering the unwelcomeness requirement as part of the "affecting a term or condition" element of a Title VII action in hostile environment cases). 
have to involve an tangible employment decision (e.g., demotion) or qualify as "severe or pervasive" enough to create an objectively "abusive work environment." 107

The second step would focus on the issue of causation and depend on the type of harassment alleged. In a quid pro quo claim, the court would determine the sexual orientation of the harasser and whether sexual proposals were implicitly or explicitly made (Oncale's first evidentiary route). ${ }^{108}$ In a hostile work environment claim, the court would determine whether the harassment qualified as "sex-specific" (Oncale's second evidentiary route). This would include conduct that was sexual and behavior that focused on the plaintiff's sex. For example, a court should infer discrimination if the harasser repeatedly called the plaintiff a "dumb woman." ${ }^{, 09}$ For constitutional reasons, the factfinder would focus on the conduct alone and the claim would not turn on whether the plaintiff was a man or woman, heterosexual or gay. If the claim did not involve sexual proposals, sexual conduct or "sex-specific" conduct, then the court would determine whether members of one sex were treated differently than members of another (Oncale's third evidentiary route). For example, a court could infer discrimination if a supervisor repeatedly berated the women for poor performance but not the men, or if women alone were exposed to an abusive environment.

This two-step approach - building directly on Oncale and prior case lawuses a rule-like approach to adjudicate cases. That is, using the conduct of the harassment to infer discrimination has the result of prohibiting categories of behavior (e.g., all harassment that is sexual and creates a hostile work environment is prohibited). Moreover, the analysis does not look at a wide range of other factors that might be in some sense relevant, including the plaintiff's sex

107. The distinction between harassment that affects a tangible employment decision and harassment that creates an abusive work environment is important for reasons of liability. In Burlington Industries $v$. Ellerth, 524 U.S. 742 (1998), and Faragher v. City of Boca Raton, 524 U.S. 775 (1998), the Court held that liability turns on whether the victim has suffered a "tangible employment action," such as termination or the loss of a promotion; if so, then the employer is automatically liable. If it involves an abusive environment, an employer is liable unless it demonstrates that it "exercised reasonable care to prevent and correct promptly" the harassment and that the employee unreasonably failed to avoid harm by complaining to her employer or taking other appropriate actions. Faragher, 524 U.S. at 807.

108. In The Equal Protection Problem in Sexual Harassment Doctrine, I argue that this is the best way to interpret Oncale for constitutional reasons. Lehman supra note 13, at 142-54. Oncale's first evidentiary route raises an equal protection problem because it classifies plaintiffs by their sex and then treats them differently. When heterosexual men create sexually hostile work environments, female plaintiffs have to prove only that the harassment affected the "compensation, terms, conditions, or privileges" of employment to obtain a remedy. Male plaintiffs in the same position-sexually harassed by heterosexual men-must meet a higher burden by otherwise proving they were harassed "because of their sex." This differential treatment triggers constitutional scrutiny because the government must treat men and women the same unless it can provide "an exceedingly persuasive" justification for the differential treatment. The article argues that courts cannot justify treating men and women's claims differently in every sexual harassment case. The solution, which remains consistent with the language of Oncale, is for lower courts to rely on a plaintiff's sex and the harasser's sexual orientation only in quid pro quo claims of sexual harassment. $I d$.

109. In this light, we can make some progress on one court's statement that, "It is one thing to call a woman 'worthless,' and another to call her a 'worthless broad."' Steiner v. Showboat Operating Co., 25 F.3d 1459,1464 (9th Cir. 1994). Assuming that the harassment rose to a sufficiently high level, the difference may not be in the motive of the harasser but in the virtues of drawing a bright-line rule based on conduct. 
or sexual orientation. As a result, this approach would be overinclusive because it would sweep into its conduct that might not qualify as sex discrimination. The virtues of the approach, however, should be apparent from the discussion above.

\section{B. Old Doctrine: When impact proves causation under Title VII}

Some scholars have derided sexual harassment as being "treated as an exceptional and unique form of discrimination" 110 because courts have paid little attention to Title VII's "because of such individual's sex" element but simply prohibited sexual harassment per se. The analysis thus far shows that this criticism proves too much by itself because other reasons justify such an approach. But this criticism is also inaccurate because it mischaracterizes Title VII doctrine as a whole. Prohibiting sexual or sex-specific harassment-by presuming discrimination from conduct alone-fits well within the larger structure of Title VII analysis.

The Supreme Court has adopted two general theories of what constitutes prohibited discrimination under Title VII: disparate treatment and disparate impact. Disparate treatment is the "most easily understood type" 111 because it focuses on the employer's motive and proof of the employer's intent is critical. In turn, disparate treatment may be analyzed at the group or individual level.

At the group level, for example, an employer could have a policy that only women may work as nurses. Or, more commonly, the employer might have such a policy informally that is revealed by a pattern or statistical evidence demonstrating differential treatment. An individual plaintiff can also be the victim of disparate treatment (or intentional discrimination). For instance, there might be a prejudiced supervisor who-acting as the employer's agentbelieves that only women should be nurses and assigns only women to that job. In such a case, there would be no policy (by definition) and thus no group or systematic claim, but the individual would still have a claim. The focus remains whether the supervisor acted with the intent to discriminate on an invidious basis.

The second theory is disparate impact. As the Supreme Court has explained, systemic (or group) disparate impact involves "practices that are facially neutral in their treatment of different groups but that in fact fall more harshly on one group than another and cannot be justified by business necessity." 112 The key difference between disparate impact and disparate treatment is that the plaintiff does not need to prove a discriminatory motive in the policy. ${ }^{113}$ Under this theory, for example, an employer can be held liable under Title VII solely for hiring people based on minimum height and weight requirements. An employer may even violate Title VII by relying on other more subjective criteria (e.g., only

110. Willbom, supra note 4, at 677 .

111. Int'l Bhd. of Teamsters v. United States, 431 U.S. 324, 335 n.15 (1977).

112. Id.

113. Id. 
hiring "aggressive" employees) if it has a disparate impact on women and it is not a business necessity. ${ }^{114}$

The legitimacy of this theory was often questioned before it was codified in $1991^{115}$ on the ground that Title VII for did not prohibit employers from discriminating against people "because of" their height or anything except certain invidious criteria such as race and sex. ${ }^{116}$ For some this created a "paradox" because it raised the question of how an employer who uses a neutral criterion could be deemed to have made an employment decision that is based on sex. ${ }^{117}$ Nonetheless, the Supreme Court accepted the disparate impact theory under Title VII.

The important point for this article is that the claim that sexual harassment is somehow "exceptional" because it ignores harasser's intent is wrong. Before 1991, courts ignored intent whenever they decided a disparate impact claim even though the statute required "discrimination because of such individual's sex." A prima facie claim was based on the impact of the policy alone.

Thus, there exists a clear parallel between the types of claims. In a systematic disparate impact claim, the plaintiff does not need to demonstrate the employer's motivation: The impact of the policy fulfills the "because of sex" requirement. In an individual harassment claim, the plaintiff does not need to demonstrate the harasser's motivation: The discrimination element is satisfied with proof that the harassment was sexual or sex-specific. The following table demonstrates their parallel structure:

114. Under the disparate impact theory, the Supreme Court developed a three-part analysis. Griggs v. Duke Power Co., 401 U.S. 424 (1971). First, the plaintiff's prima facie case requires a showing that a facially neutral employment practice has a disproportionately adverse impact on a protected class. Once that threshold is reached, the burden of persuasion shifts to the employer to demonstrate that the challenged practice is jobrelated and justifiable as a matter of business necessity. Finally, the plaintiff has an opportunity to prove that there exists an alternative practice that would serve the employer's objectives equally well but have a less severe adverse effect. Until Wards Cove Packing Co. v. Atonio, 490 U.S. 642 (1989), the issue of business necessity was an affirmative defense, rather than part of the plaintiff's case. In Wards Cove, the Court placed the burden of proof on the plaintiff. Congress overtumed this burden in 1991. See infra note 115.

115. Congress codified the disparate impact cause of action in the Civil Rights Act of 1991 . See 42 U.S.C. $\S 2000 \mathrm{e}-2(\mathrm{k})(1)(\mathrm{A})(1994)$. The Act served to overrule some aspects of Wards Cove, in which the Supreme Court had announced a series of changes in disparate impact doctrine. Most notable among these pronouncements was a new rule that the issue of "business necessity" was not to be seen as an affirmative defense but as part of the plaintiff's case, id. at $659-60$, and a redefinition of the concept of business necessity that was more a notion of reasonable justification than of necessity, id. at 659. In the 1991 Act, Congress made it clear that the burden of persuasion on the question of business necessity rests on the employer, not the plaintiff. Moreover, the Act reinstated judicial interpretations of "consistent with business necessity" and "job relatedness" that predated Wards Cove.

The important point for this article, however, is not the contours of disparate impact analysis before or after the 1991 Act. The important point is to notice is that impact alone-without proof of individual motivesatisfied Title VII.

116. E.g., Earl M. Maltz, The Legacy of Griggs v. Duke Power Co.: A Case Study in the Impact of a Modernist Statutory Precedent, 1994 UTAH L. REV. 1353 (1994) (characterizing the Griggs decision as an example of the influence of independent, court-made policy judgments in statutory interpretation).

117. Steven L. Willbom, The Disparate Impact Model of Discrimination and Limits, 34 AM. U. L. REV. 799, 803 (1985); see also Owen Fiss, A Theory of Fair Employment Laws, 38 U. CHI. L. REV. 235, 297 (1971) (" $[\mathrm{H}]$ ow can an employment decision based on the individual's nonperformance under a facially innocent criterion be deemed to be an employment decision based on the individual's race?"). 


\begin{tabular}{|c|c|c|}
\hline \multirow[t]{2}{*}{ Type of Claim } & \multicolumn{2}{|c|}{ Proving the "because of such individual's sex" element } \\
\hline & $\begin{array}{l}\text { Individualized } \\
\text { inquiry into } \\
\text { motivation } \\
\end{array}$ & Conduct alone proves element \\
\hline Group Claim: & $\begin{array}{l}\text { Employer's policy: } \\
\text { discrimination } \\
\text { proved by } \\
\text { 1) explicit policy or } \\
\text { 2) implicit policy } \\
\text { demonstrated by } \\
\text { pattern of } \\
\text { differential } \\
\text { treatment } \\
\end{array}$ & $\begin{array}{l}\text { Employer's explicit policy: } \\
\text { motivation ignored if it has } \\
\text { disparate impact }\end{array}$ \\
\hline $\begin{array}{l}\text { Individual Claim: } \\
\text { 1) Adverse } \\
\text { Tangible } \\
\text { Employment } \\
\text { Decision" } 18 \text { or } \\
\text { 2) Harassment } \\
\text { affecting "terms } \\
\text { and conditions""19 }\end{array}$ & $\begin{array}{l}\text { Demonstrated by } \\
\text { differential } \\
\text { treatment (Oncale's } \\
3^{\text {rd }} \text { evidentiary } \\
\text { route) }\end{array}$ & $\begin{array}{l}\text { Motivation ignored if it is } \\
\text { 1) sexual conduct (Oncale's } 1 \text { st } \\
\text { evidentiary route) } \\
\text { 2) sex-specific (Oncale's } 2^{\text {nd }} \\
\text { evidentiary route) }\end{array}$ \\
\hline
\end{tabular}

Although outside the scope of this article, one could argue that the systematic disparate impact claims are justified by the same reasons advocated here. Systematic disparate impact is certainly overinclusive if one reads the statute as prohibiting intentional discrimination. Yet it simplifies the law's approach in deciding cases and thus lowers decision costs, promotes equal treatment of similar cases, and increases predictability for employers and employees.

\section{Same Doctrine: When conduct proves causation outside discrimination law}

In a number of areas of law outside discrimination law, courts must resolve questions of causation. That is, they must determine whether something happened "because of" something else. Generally, these areas require judges to answer a "but for" question and proof of certain facts alone cannot satisfy this element. However, in each area "exceptions" to this general approach exist. This section provides thumbnail sketches of four diverse areas of law that require

118. The employer would be automatically liable if the harassment involves a "tangible employment decision" under Burlington Indus. v. Ellerth, 524 U.S. 742 (1998). See supra note 107.

119. The employer would be liable if the harassment creates an abusive environment unless he or she demonstrates that he or she "exercised reasonable care to prevent and correct promptly" the harassment and that the employee unreasonably failed to avoid harm by complaining to her employer or taking other appropriate actions under Burlington, 524 U.S. 742 (1998). See supra note 107.

120. Oncale's first evidentiary route also looks at the sexual orientation of the harassers, and it should be applied only to quid pro quo cases for constitutional reasons of equal protection. See supra note 108. 
judges to determine causation: common law negligence, the National Labor Relations Act, SEC Rule 10(b)(5) and Sixth Amendment "Strickland" rights. In each, courts use presumptions or inferences based on a fact to fulfill the causation element.

This section's goal, however, is not to detail or defend the merits of each area of law. Many reasons support these positions and a discussion of them is outside the scope of this article. Rather, this section's purpose is to demonstrate that it is not extraordinary or exceptional for conduct to satisfy a causation requirement or for courts simply to avoid an individualized inquiry altogether, even while maintaining that as a general matter causation must be proved on case-by-case. While such approaches are always overinclusive, they are still acceptable.

\section{Common Law Negligence}

Begin with the common law, which holds people liable for accidents that happen "because of" their negligence. In general, courts do not hold defendants liable for an accident or injury because accidents happen even when one is not negligent. ${ }^{121}$ Thus, courts have often said, "negligence must be proved, and never will be presumed." 122

Despite such an emphatic statement, doctrinal exceptions exist. Under the doctrine of res ipsa loquitur (meaning, it "speaks for itself"), courts find defendants liable solely because it was a certain type of accident (e.g., the explosion of a water heater, the falling of an elevator, etc.). ${ }^{123}$ That is, courts ignore whether in that individual case it happened "because of" negligence. This approach rests on the acknowledgement that res ipsa loquitur sweeps too broadly because it holds all defendants liable even though in many cases no one acted negligently.

Courts also typically presume causation in product liability cases involving the "failure to warn."124 Thus, courts presume "that the consumer would have read any warning provided by the manufacturer, and acted so as to minimize the risks," ${ }^{125}$ except in unusual cases. ${ }^{126}$ This approach is flawed because a number of consumers would have been undoubtedly injured even with the label. As a result, the defendants are held liable for injuries that they did not cause. But by assuming causation the court avoids the need to make particularized inquiry. This "generalized" approach covering the whole class of cases is preferable

121. W. Page Keeton et al., Prosser \& KeEton on the LAW of TORTS § 39, at 242 (5th ed. 1984 \& Supp. 1995).

122. Id.

123. Id. at 244-45.

124. Robert N. Strassfeld, If . . : Counterfactuals in the Law, 60 GEO. WASH. L. REV. 339, 359 (1992).

125. Reyes v. Wyeth Lab., 498 F.2d 1264, 1281 (5th Cir. 1974) (applying Texas law); see also Strassfeld, supra note 124 , at $359 \mathrm{n} .99$ (citing cases that apply presumption).

126. E.g., Thomas v. Balt. \& O.R.R., 310 A.2d 186 (Md. Ct. Spec. App. 1973) (finding presumption rebutted by evidence of plaintiff's knowledge of danger even in absence of waming signs). 
because it lowers decision costs, treats all the plaintiff equally and promotes predictability for the companies and consumers.

\section{Section $8(a)(3)$ of the NLRB}

Section 8(a)(3) of the National Labor Relations Act makes it an unfair labor practice for an employer "by discrimination in regard to hire or tenure of employment or any term or condition of employment to encourage or discourage membership in any labor organization." 127 The Supreme Court has held that section 8(a)(3) requires an anti-union motive. ${ }^{128}$ Thus, an "act is not by itself unlawful unless intended to prejudice the employees' position because of their membership in the union." 129

As one might expect, employers typically deny that an employee's protected status played any role in their challenged behavior (i.e., dismissal). ${ }^{130} \mathrm{As}$ a result, the question for a court becomes one of motive: Did the employer act a certain way because of an anti-union animus? ${ }^{131}$ of course, another way to put this is whether the employer would have treated the plaintiff the same way if they were not in a union. In general, if anti-union animus drives the decision, then the employer has violated $\S 8(\mathrm{a})(3)$; if not, the behavior is lawful. ${ }^{132}$ For example, it is unlawful for an employer to fire a union leader to harm the union, but it is completely lawful to dismiss a union leader because he violated shop rules. ${ }^{133}$

The Supreme Court has carved out an exception to this rule, however. While maintaining that motive is an element of $\S 8(\mathrm{a})(3),{ }^{134}$ the Court has held that behavior which is "inherently discriminatory conduct" can violate § 8(a)(3) without proof of unlawful motive. ${ }^{135}$ For example, regardless of motive or even an employer's need to maintain operations, it is unlawful under $\S 8(a)(3)$ for an employer to offer super-seniority (e.g., an additional credit of twenty years' seniority) to workers who replace striking employees or strikers who return to work immediately. ${ }^{136}$ Such conduct "speaks for itself" ${ }^{137}$ and is prohibited by $\S$ $8(a)(3)$.

127. 29 U.S.C. $\$ 158(a)(3)(2000)$.

128. See Radio Officers v. NLRB, 347 U.S. 17, 43 (1954) (holding employer's "real motive" is decisive under section 8(a)(3)).

129. NLRB v. Brown, 380 U.S. 278, 286 (1965).

130. Rebecca Hanner White, Modern Discrimination Theory and the National Labor Relations Act, 39 WM. \& MARY L. REV. 99, 125-26 (1997).

131. Id.

132. Id.

133. American Shipbuilding Co. v. NLRB, 380 U.S. 300, 311 (1965).

134. NLRB v. Great Dane Trailers Inc., 388 U.S. 26, 33 (1967) ("The statutory language 'discrimination ... to . . . discourage' means that the finding of a violation normally turns on whether the discriminatory conduct was motivated by an anti-union purpose.").

135. See id; see also Barbara J. Fick, Inherently Discriminatory Conduct Revisited: Do We Know It When We See It?, 8 HofSTRA LAB. L.J. 275, 276 (1991).

136. NLRB v. Erie Resistor Corp., 373 U.S. 221, 227-37 (1963).

137. Fick, supra note 135 , at 275. 


\section{SEC Rule 10b-5}

The Securities and Exchange Commission's Rule 10b-5 prohibits fraudulent conduct in connection with the purchase or sale of any security. ${ }^{138}$ Under $10 \mathrm{~b}-5$, a plaintiff may recover damages for a defendant's conduct provided that the plaintiff can prove reliance on the defendant's misrepresentation or omission. In this context, courts consider reliance a synonym for "but for" or "in fact" causation. ${ }^{139}$ Courts have held that such reliance is "a matter of individual proof ${ }^{\prime 140}$ that is established only if the evidence shows that the misrepresentation was a substantial factor in determining the course of conduct that resulted in his loss. ${ }^{141}$

The Supreme Court recognized the difficulty of proving reliance on the nondisclosure of information in Affiliated Ute Citizens v. United States. ${ }^{142}$ Rather than require an individual to prove that he or she would have acted otherwise "but for" the non-disclosure, the Court ruled that the defendant's failure to disclose material information establishes the requisite causation when there is a duty to disclose (such as a fiduciary duty). ${ }^{143}$ In short, the Court changed the inquiry from "Would the plaintiff still have acted the same had the information been disclosed?" to asking, "Was the information material enough to establish a presumption of reliance?" While defendants technically have the ability to rebut this presumption, it is virtually impossible to do this. ${ }^{144}$ Thus, the Court has created a de facto irrebuttable presumption of reliance in cases of nondisclosure.

\section{Ineffective Counsel and Strickland v. Washington}

In Strickland v. Washington, ${ }^{145}$ the Supreme Court established a two-part test to evaluate criminal defendants' claims that their lawyer provided ineffective assistance. First, the defendant must prove that his counsel's performance fell below an objective standard of reasonableness. Second, the defendant must show "a reasonable probability that, but for counsel's unprofessional errors, the result of the proceeding would have been different." ${ }^{146}$

138. 17 C.F.R. $\$ 240.10 \mathrm{~b}-5$ (2000). Rule 10b-5 is promulgated under the Securities Exchange Act of 1934,15 U.S.C. $\S 78 \mathrm{j}(\mathrm{b})(2000)$.

139. See List v. Fashion Park, Inc., 340 F.2d 457, $462-63$ (2d Cir. 1965) (The test of 'reliance' is whether "the misrepresentation is a substantial factor in determining the course of conduct which results in [the recipient's] loss. The reason for this requirement . . . is to certify that the conduct of the defendant actually caused the plaintiff's injury." (quoting RESTATEMENT OF TORTS $§ 546$ (1938) (additional citations omitted))).

140. Huddleston v. Herman \& MacLean, 640 F.2d 534, 549 (5th Cir. Unit A Mar. 1981); see also List, 340 F.2d at 462-63.

141. Huddleston, 640 F.2d at 549 .

142. 406 U.S. 128 (1972).

143. Id. at 153-54.

144. Joseph De Simone, Should Fraud on the Market Theory Extend to the Context of Newly Issued Securities?, 61 FORDHAM L. REV. 151, 166 (1993).

145. 466 U.S. 668 (1984).

146. Id. at 694 (emphasis added). 
Some circumstances constitute per se prejudice, however, and courts presume the error caused harm. For example, courts will assume prejudicial error if the defendant demonstrates an actual conflict of interest with counsel and a lapse in representation. ${ }^{147}$ Courts have also found that an attorney's absence during a critical stage of the trial qualifies as per se prejudicial. ${ }^{148}$ Notably, the Supreme Court has justified irrebuttable presumptions under this analysis in part because when prejudice is highly likely, a "case-by-case inquiry into prejudice is not worth the cost." 149

\section{CONCLUSION}

It is important to distinguish the two claims that this article makes. The first claim is courts may legitimately interpret a statute in an overinclusive, rule-like fashion. Although this claim is important, it should be uncontroversial because courts commonly use rule-like approaches to decide individual cases. The second claim is that in the Title VII context, courts should prohibit all harassment that is sexual or sex-specific regardless of the sex or sexual orientation (or any other personal characteristic) of the plaintiff. This is the bolder claim. It is also where the discussion over prohibiting sexual harassment and Title VII's appropriate scope should take place.

All sexual harassment may not qualify as sex discrimination but one must weigh the problem of taking an overinclusive approach against what is lost if the issue is approached case-by-case. A rule-free, individualized approach increases the costs of making the decision, increases the amount of arbitrariness in the decision-making, and decreases the law's predictability for employers and employees. At the same time, an individualized approach that looks at the sex or sexual orientation of the plaintiffs to determine liability may run afoul of the Constitution. Once all of this is considered, we may well agree that all sexual harassment in the workplace should be prohibited.

147. United States v. O'Neil, 118 F.3d 65, 71 (2d Cir. 1997).

148. E.g., Green v. Am, 809 F.2d 1257, 1262-63 (6th Cir. 1987), vacated, 484 U.S. 806 (1987), reinstated on remand, 839 F.2d 300 (6th Cir. 1988) ("[There are,] however, circumstances that are so likely to prejudice the accused that the cost of litigating their effect in a particular case is unjustified. ... [For example,] [a]bsence from the proceedings is deficient performance as a matter of law, and prejudice is presumed." (emphasis added)); Martin v. Rose, 744 F.2d 1245, 1250-51 (6th Cir. 1984) (holding that counsel's lack of participation rendered adversarial process unreliable, constituting per se prejudice).

149. Strickland, 466 U.S. at 692. 
APPENDIX:

Brief Summary of Major Statistics on Sexual Harassment:

U.S. MERIT SYSTEMS PROTECTION BOARD'S SURVEY $(1980,1987,1994)$

1. How Many Employees Experienced Sexually Harassing Behavior in the Previous Two Years? ${ }^{150}$

\begin{tabular}{|l|l|l|}
\hline & Women (\%) & Men (\%) \\
\hline 1980 & 42 & 15 \\
\hline 1987 & 42 & 14 \\
\hline 1994 & 44 & 19 \\
\hline
\end{tabular}

2. The Harasser's Sex (1994) $?^{151}$

\begin{tabular}{|l|l|l|}
\hline & \multicolumn{2}{|l|}{ The Victim's Sex } \\
\hline The Harasser's sex & Women (\%) & Men (\%) \\
\hline Men & 93 & 21 \\
\hline Women & 1 & 65 \\
\hline $\begin{array}{l}\text { Mixed group of } \\
\text { men and women } \\
\text { or unknown }\end{array}$ & 6 & 14 \\
\hline
\end{tabular}

150. U.S. Merit Systems Protection Board, Sexual harassment in the Federal Workplace: Trends, Progress, Continuing Challenges 14 (1995).

151. Id. at 18. 
3. Forms of Sexual Harassment: Respondents Who Experienced the Indicated Behaviors During the Preceding Two Years (1994) ${ }^{152}$

\begin{tabular}{|l|l|l|}
\hline & Women (\%) & Men (\%) \\
\hline $\begin{array}{l}\text { Sexual remarks, } \\
\text { jokes, teasing }\end{array}$ & 37 & 14 \\
\hline $\begin{array}{l}\text { Sexual looks, } \\
\text { gestures }\end{array}$ & 29 & 9 \\
\hline $\begin{array}{l}\text { Deliberate } \\
\text { touching, } \\
\text { comering }\end{array}$ & 24 & 8 \\
\hline Pressure for dates & 13 & 4 \\
\hline $\begin{array}{l}\text { Suggestive letters, } \\
\text { calls, materials }\end{array}$ & 10 & 4 \\
\hline Stalking & 7 & 2 \\
\hline $\begin{array}{l}\text { Pressure for sexual } \\
\text { favors }\end{array}$ & 7 & 2 \\
\hline $\begin{array}{l}\text { Actual/attempted } \\
\text { rape, assault }\end{array}$ & 4 & 2 \\
\hline
\end{tabular}


Three Studies of the SeXual Harassment of Men by Craig R. Waldo, JENNIFER L. BERDAHL AND LOUISE F. FITZGERALD ${ }^{153}$

1. Forms of Harassment ${ }^{154}$

\begin{tabular}{|l|l|l|l|}
\hline & $\begin{array}{l}\text { Study 1 (\% } \\
\text { of men } \\
\text { surveyed) }\end{array}$ & $\begin{array}{l}\text { Study 2 (\% } \\
\text { of men } \\
\text { surveyed) }\end{array}$ & $\begin{array}{l}\text { Study 3 (\% } \\
\text { of men } \\
\text { surveyed) }\end{array}$ \\
\hline $\begin{array}{l}\text { Overall rate } \\
\text { of sexual } \\
\text { harassment } \\
\text { of men }\end{array}$ & 46.9 & 47.8 & 49.8 \\
\hline $\begin{array}{l}\text { Sexual } \\
\text { coercion }\end{array}$ & 1.9 & 0 & 3.6 \\
\hline $\begin{array}{l}\text { Unwanted } \\
\text { sexual } \\
\text { advances }\end{array}$ & 17.9 & 11.5 & 29.0 \\
\hline $\begin{array}{l}\text { Lewd } \\
\text { comments }\end{array}$ & 38.7 & 37.8 & 44.1 \\
\hline $\begin{array}{l}\text { Negative } \\
\text { remarks } \\
\text { about men }\end{array}$ & 24.0 & 25.6 & 33.3 \\
\hline $\begin{array}{l}\text { Enforcing the } \\
\text { male gender } \\
\text { role }\end{array}$ & 11.1 & 6.7 & 9.3 \\
\hline
\end{tabular}
(1998).

153. Craig R. Waldo et. al, Are Men Sexually Harassed? If So, by Whom?, 22 LAW \& HUM. BEHAV. 59 154. Id. at 67 . 
2. Who harasses men? ${ }^{155}$

\begin{tabular}{|l|l|l|l|}
\hline $\begin{array}{l}\text { The } \\
\text { Harasser's } \\
\text { Sex }\end{array}$ & $\begin{array}{l}\text { Study 1 (\% of } \\
\text { men harassed) }\end{array}$ & $\begin{array}{l}\text { Study 2 (\% of } \\
\text { men } \\
\text { harassed) }\end{array}$ & $\begin{array}{l}\text { Study 3 (\% of } \\
\text { men harassed) }\end{array}$ \\
\hline $\begin{array}{l}\text { Men or } \\
\text { mostly } \\
\text { men }\end{array}$ & 52.7 & 50.2 & 39.8 \\
\hline $\begin{array}{l}\text { Women or } \\
\text { mostly } \\
\text { women }\end{array}$ & 30.1 & 31.7 & 31.9 \\
\hline $\begin{array}{l}\text { Both men } \\
\text { and } \\
\text { women }\end{array}$ & 17.2 & 19.1 & 28.3 \\
\hline
\end{tabular}

\section{OTHER STUDIES ON SEXUAL HARASSMENT}

1. Navy-wide survey (1989) of personnel indicating they were harassed by someone of the same sex ${ }^{156}$

\begin{tabular}{|l|l|}
\hline Women (\%) & Men (\%) \\
\hline 0.5 & 40 \\
\hline
\end{tabular}

2. Department of Defense survey (1988) of active-duty personnel ${ }^{157}$

Personnel reporting sexual harassment in the previous year

\begin{tabular}{|l|l|l|}
\hline & Women (\%) & Men (\%) \\
\hline $\begin{array}{l}\text { Reporting sexual } \\
\text { Harassment }\end{array}$ & 64 & 17 \\
\hline
\end{tabular}

Percent of Sexual Harassment cases involving perpetrators of their victim's gender

\begin{tabular}{|l|l|l|}
\hline & Women (\%) & Men (\%) \\
\hline $\begin{array}{l}\text { Same-Sex } \\
\text { Harasser }\end{array}$ & 3 & 37 \\
\hline
\end{tabular}

155. Id. at 69.

156. Amy L. Culbertson et al., Assessment of Sexual HaRassment in the Navy: Results of the 1989 NAVY-WIDE SURVEY (1992).

157. John B. Pryor \& Nora J. Whalen, A Typology of Sexual Harassment: Characteristics of Harassers and Social Circumstances Under Which Sexual Harassment Occurs, in SEXUAL HaRAsSMeNT: TheORY, RESEARCH, TREATMENT 129, 140-41 (William O'Donohue ed., 1997). 
NUMBER OF COMPLAINTS FILED WITH THE EEOC ${ }^{158}$

\begin{tabular}{|l|l|l|l|l|l|l|l|l|}
\hline & 1992 & 1993 & 1994 & 1995 & 1996 & 1997 & 1998 & 1999 \\
\hline $\begin{array}{l}\text { Overall } \\
\text { Complaints } \\
\text { of } \\
\text { Harassment }\end{array}$ & 10,532 & 11,908 & 14,420 & 15,549 & 15,342 & 15,889 & 15,618 & 15,222 \\
\hline $\begin{array}{l}\text { \% Filed by } \\
\text { Men }\end{array}$ & 9.1 & 9.1 & 9.9 & 9.9 & 10.0 & 11.6 & 12.9 & 12.1 \\
\hline $\begin{array}{l}\text { Number } \\
\text { Found to } \\
\text { Have } \\
\text { Reasonable } \\
\text { Cause }\end{array}$ & 285 & 366 & 520 & 451 & 577 & 808 & 1,047 & 1,180 \\
\hline $\begin{array}{l}\text { \% with } \\
\text { Reasonable } \\
\text { Cause }\end{array}$ & 3.8 & 3.7 & 4.5 & 3.3 & 3.6 & 4.7 & 6.1 & 7.1 \\
\hline
\end{tabular}

